\title{
Öğretmenlerin Mesleki Sorun Tanımları: Okul Öncesi Öğretmenleri Bağlamında Bir Değerlendirme ${ }^{1}$
}

\author{
Cansu BASTTURAN* \\ Ertan GÖRGÜ ${ }^{* *}$
}

\begin{abstract}
Öz: Araştırmanın amacı devlet ve özel okul öncesi eğitim kurumlarında görev yapan öğretmenlerin mesleki sorun tanımlarını incelemektir. Çalışma grubu, 2017-2018 eğitim-öğretim yılında İstanbul ili Anadolu Yakası'nda devlet ve özel okul öncesi eğitim kurumlarında devlet ve özel okul öncesi eğitim kurumlarında görev yapmakta olan, kartopu örnekleme yoluyla seçilmiş 118 okul öncesi öğretmeninden oluşmuştur. Karma desenli olan bu çalışmanın veri toplama sürecinde araştırmacı tarafından geliştirilmiş olan okul öncesi öğretmenleri için "Demografik Bilgi Formu" ve yarı yapılandırılmış "Öğretmen Görüşme Formu" kullanılmıştır. Elde edilen bulgular içerik analizi, çapraz tablo ve ki kare yöntemiyle değerlendirilmiştir. Devlet ve özel kurumlarda görev yapan okul öncesi öğretmenlerin mesleki sorunlarının karşılaştırılması sonucunda; devlet okullarında görev yapan öğretmenlerin okul şartları, sınıf materyalleri, sınıf mevcutları ve mola ile ilgili daha yüksek düzeyde sorun belirttikleri, özel okullarda görev yapan öğretmenlerin ise, değersizlik, maaş, çalışma saatleri ile ilgili daha yüksek düzeyde sorun belirttikleri tespit edilmiştir.
\end{abstract}

Anahtar Sözcükler: Okul Öncesi Öğretmeni, Kamu Anaokulu, Özel Anaokulu, Sorun Tanımı

\section{Occupational Problem Definitions of Teachers: An Evaluation in the Context of Preschool Teachers}

\begin{abstract}
The aim of the study is to examine the professional problem definitions of teachers working in state and private pre-school education institutions. The study group consisted of 118 pre-school teachers selected by snowball sampling who have worked in state and private pre-primary education institutions on the Anatolian side of Istanbul in 2017-2018 academic year. Demographic Information Form and semi-structured Teacher Interview Form were used for the preschool teachers developed by the researcher during the data collection process where both quantitative and qualitative methods were used. The results were evaluated with content analysis, cross-table and chi-square method. The definitions of the identified problems were compared and evaluated in the context of the state and private institutions where teachers work. As a result of the study, it was found that teachers working in public schools indicated higher level problems related to school conditions, class materials, class sizes and breaks. Teachers working in private schools indicated a higher level of problem about worthlessness, salary and working hours.
\end{abstract}

Keywords: Preschool Teacher, Public Kindergarten, Private Kindergarten, Problem Definition

1 Bu çalışma ilk yazarın İstanbul Okan Üniversitesi, Sağlık Bilimleri Enstitüsü, Çocuk Gelişimi Yüksek Lisans Programında, ikinci yazar danışmanlığında hazırladığı tezden türetilmiştir.

* MEF Okulları, İstanbul, Türkiye, e-posta: cansu_basturan@hotmail.com, ORCID: https://orcid.org/0000-0001-7226-1697

** İstanbul Medeniyet Üniversitesi, Eğitim Bilimleri Fakültesi, Temel Eğitim Bölümü, İstanbul, Türkiye, e-posta:ertangorgu@gmail.com, ORCID: https://orcid.org/0000-0002-1932-6049
} 
Milli Eğitim Temel Kanunu'na göre okul öncesi eğitim; eğitimin zorunlu olduğu yaşa gelmeyen çocukların zihin, beden ve duygu gelişimine katkıda bulunmak, uygun alışkanlıklar kazanmalarına yardımcı olmak, onları ilkokul çağına hazırlamak, şartları uygun olmayan aile ve çevreden gelen çocuklara ortak yetişme ortamı hazırlamak ve çocukların Türkçeyi güzel ve etkin konuşmalarını sağlamak amaçlarına sahip olan eğitim olarak açıklanmaktadır (Burhan, 2016). Bu tanımın yanı sıra farklı araştırmacılar tarafından yapılan çeşitli okul öncesi eğitim tanımları da bulunmaktadır. Farklı bir tanıma göre okul öncesi eğitim; doğumdan ilkokul sürecinin başına kadar geçen dönemde çocukların kişilik özelliklerinin gelişimini, çeşitli çevresel etkenler ve toplumsal değerler aracilığıyla kimlik gelişimlerini şekillendiren eğitim süreci olarak açılanmaktadır (Poyraz, 2001). Okul öncesi eğitim, 3672 aylık çocukların kişisel gelişimine uygun, birçok çevre uyarıcıları yoluyla sosyal, zihinsel, duygusal ve bedensel olarak gelişimlerine destek olmaktadır. Bu aşamada çocuk, toplum değerlerine uygun şekilde ilkokul sürecine hazırlanmaktır (Yaşar, 2004). Çocuklara verilecek olan okul öncesi eğitim ile çocukların yeterlilikleri, yetersizlikleri ve duygusal sorunları önceden fark edilebilmekte ve böylece gerekli önlemler alınabilmektedir. Böylelikle çocukların uygunsuz çevre koşullarından olumsuz şekilde etkilenmelerinin önüne geçilebilmekte ve gerekli fiziksel aktiviteler ile birlikte çocuğun beden gelişimi desteklenerek okul öncesi eğitim kurumlarında yaşıtlarıyla birlikte güvenli bir ortam içerisinde bulunma firsatı verilmektedir (Ekici, 2013).

Çocukların en hızlı gelişim evresi olarak nitelendirilen okul öncesi dönemde, hem akademik açıdan başarılı olmaları hem de sosyal açıdan gelişmeleri için etkin bir okul öncesi eğitim almaları oldukça önemlidir. Yapılan çalışmalarda okul öncesi eğitim almış olan çocukları, okul öncesi eğitimi almamış çocuklara göre gelişim alanlarının tümünde daha üstün geldikleri görülmüştür (Alabay ve Yağan, 2015). 0-6 yaş dönemini kapsayan okul öncesi dönemi, temel alışkanlıkların kazanıldığı, bilişsel yeteneklerin şekillendiği ve öğrenmenin en yüksek seviyede olduğu dönemdir. Bu nedenle okul öncesi eğitimin niteliğinin arttırılması ve olabilecek en iyi şekilde düzenlenmesi önem taşımaktadır.

20. yüzyıl ile birlikte birçok ülkede eğitime verilen önem artmış, farklı okul öncesi eğitim örnekleri denenmiş, farklı kuruluşların destekleri ile çeşitli çalışmalar gerçekleştirilmiştir (Akkurt, 2008). Bu konu hakkında yapılmış olan çalışmalar, okul öncesi eğitime devam eden çocukların gelişimlerinde, uyum becerilerinde ve kariyerlerinde, okul öncesi eğitime devam etmeyen çocuklara göre pozitif bir artış olduğunu ortaya koymaktadır (Atay, 2005). Bloom tarafından yapılan araştırmada, 17 yaşına kadar olan zihinsel gelişimin \%50'sinin 4 yaşına, \%30'unun 4 yaşından 8 yaşına, \%20'sinin ise 8 yaşından 17 yaşına kadar oluştuğu ortaya konmuştur. Bu doğrultuda çocuğun yeteneklerinin geliştirilebilmesi ve davranışlarının güçlendirilebilmesi için erken yaşlarda eğitim oldukça büyük önem taşımaktadır. Bunun gerçekleştirilebilmesi için de iyi planlanmış bir okul öncesi eğitim programı gerekmektedir (Poyraz, 2001).

Okul öncesi eğitim, çocukların duygu ve düşünceleri özgürce ifade edebilmesini, araştırmacı, meraklı ve sorunlara faklı çözümler getiren çevresine karşı duyarlı, saygılı ve öz eleştiri yapabilen kişiler yetiştirmeyi amaçlamaktadır (Şahin, 2009). Bu amaçların gerçekleştirilebilmesi için öncelikle eğitim programlarının doğru ve en iyi şekilde hazırlanması gerekmektedir. Kapsamlı bir eğitim programı içerisinde öncelikle çocukların yaş, gelişim ve eğitim gibi nitelikleri göz önünde bulundurulmalı ve tüm çocukların faaliyetlere katılımı sağlanmalıdır (Temel, Kandır, Erdemir ve Koçer-Çiftçibaşı, 2005). Çocukların gelişimsel, çevresel ve eğitsel ihtiyaçlarının karşılanması, eğitimde fırsat eşitliğinin sağlanması ile farklı ortamlardan ve olumsuz etkilenebilecekleri çevrelerden gelmelerine karşın üretken ve paylaşan kişiler olmayı öğrenmeleri okul öncesi eğitimin temel hedeflerini oluşturmaktadır (Çetinkaya, 2010; Gürkan ve Haktanır, 2006). Okul öncesi dönemde eğitim verecek olan öğretmenlerin aktif eğitim yöntemlerini bilmesi ve doğru şekilde uygulaması etkili bir öğrenim için son derece gereklidir (Koşucu, 2016).

Okul öncesi eğitimde en önemli değeri oluşturan öğretmen, annesinden ilk defa ayrılarak gün boyu ayrı kalmak zorunda olan çocuğun karşılaştığı ilk kişidir. Çocuk yaşadığ1 problemlerde, okuldaki eğitiminin en başından itibaren öğretmenine başvurmaktadır. Günün büyük kısmını birlikte geçiren çocuklar, öğretmenini hem eğiticisi hem öğreticisi hem de kendisine arkadaşlık eden kişi olarak 
Öğretmenlerin Mesleki Sorun Tanımları: ...

görmektedir (Oktay, 2000). Okul öncesi eğitimde öğretmen, çocuk karşısında bir anne modeli oluşturduğu için öğretmenin çocuk ile olan sevgiye ve güvene dayalı ilişkisi oldukça önemlidir. Bu doğrultuda öğretmenin, çocuğun ailesini tanıması ve işbirliği içinde olması çocuğun gelişiminin sağlıklı bir biçimde sürdürülebilmesi için önemlidir (Meydan, 1984).

Okul öncesi eğitimin her ne kadar yadsınamaz bir önemi olsa da okul öncesi eğitim veren kurumlarda birtakım sıkıntılar ortaya çıkmaktadır. Okul öncesi eğitimi veren okullar için Milli Eğitim Bakanlığı tarafından hem devlet hem de özel kurumlara bazı standartlar getirilmiştir. Fakat söz konusu kurumlar arasında farklılıkların var olması birtakım sorunları da beraberinde getirmektedir. Bu sorunlardan en çok etkilenen kişilerin öğretmenler olduğu belirtilmektedir. Öğrencilerin eğitiminden sorumlu olan öğretmenlerin verecekleri eğitimin kaliteli ve nitelikli olabilmesi adına öğretmenlerin yaşadıkları sorunların tespit edilerek çözülmesi gerekmektedir (Taner-Derman ve Başal, 2010). Tüm Öğretmenler Birleşme ve Dayanışma Derneği [TÖB-DER] tarafından UNESCO Milli Daimi Komisyonuna sunulan rapor neticesinde öğretmenlerin genellikle geçim sıkıntısı, güvenlik, hukuk, öğretmen dağılımı, atamalar ve öğretmenlerin gruplanması konularında sıkıntılar yaşadıkları tespit edilmiştir (Demir ve Arı, 2013). Özel okullarda eğitim veren öğretmenlerin işçi kadrosunda, devlet okullarındaki öğretmenlerin ise memur kadrosunda yer aldığı, bu sebeple iki öğretim kurumunda öğretmenlere yönelik ödüllendirme arasında da fark olduğu anlaşılmaktadır. Ayrıca, özel okulların para karşılığı eğitim vermesi ile birlikte fiziki yapılarının ve teknik donanımlarının devlet okulları karşısında daha iyi olması ve özel okullardaki öğretmen ücretlerinin devlet okullarına göre daha tatmin edici olması bu iki okulda eğitim veren öğretmenlerin iş tatminleri arasında birtakım farklılıkların ortaya çıkmasına neden olmaktadır (Genç, 2006). Özel okullarda çalışan öğretmenler kendilerini geliştirebilmek adına alanında uzman kişilerden seminerler alarak gerekli donanıma sahip olabilme şansı elde edebilmektedir. Böylece özel okul öğretmenlerinin motivasyon seviyeleri de yüksek olmaktadır (Kandemir, 2015). Fakat devlet okullarında eğitim veren öğretmenlerin böyle bir şansı bulunmamaktadır. Özel okullar kayıtlarını kontrol altında tutabildiklerinden sınıf mevcutlarının 15-18 arası olduğu anlaşılmaktadır (National Centre for Educational Statistics, 1996). Devlet okulları ise çocukların başarı düzeyi, derslere katılımdaki yetersizliği ve sosyoekonomik durumuna bakmaksızın kaydetmek durumundadır. Bununla birlikte sınıf mevcudu az olan okullarda ders işlemenin daha kolay olduğu ve daha nitelikli ders işlendiği göz önünde bulundurulacak olursa devlet okullarındaki sınıf mevcutlarının oldukça yüksek olmasının burada görev yapan öğretmenler için bir dezavantaj oluşturduğu anlaşılacaktır.

Türkiye'de okul öncesi eğitim ile ilgili önemli gelişmelerin 1960'lı yıllarda başladığ 1 ancak bu gelişmelerin eğitim sisteminin gereksinimlerini niteliksel ve niceliksel yönden karşılamadığı görülmektedir (Taner-Derman ve Başal, 2010). Yapılan çalışmalarla da etkili bir eğitim-öğretim için öğretmen kriterlerinin önemli olduğu belirlenmiştir (Ekinci, 2010). Bu bağlamda okul öncesi eğitimde sorunlarla karşı karşıya kalınmaktadır. Kurumlarda yaşanan sorunlardan en fazla etkilenen kişinin öğretmen olduğu bilinmektedir. Bu sebeple sorunların tespit edilmesinin ve çözümlenmesinin önemli olduğu vurgulanmaktadır (Demir ve Arı, 2013). Okul öncesi öğretmenleriyle yapılan araştırmalarda okulun ve sınıfın fiziki imkanlarının yetersizliği, materyallerin eksikliği, programın ve içeriğinin eksikliği, okul idaresinin engelleri gibi sorunlarla karşılaştıkları saptanmıştır (Kök, Küçükoğlu, Tuğluk ve Koçyiğit, 2007). Türkiye'de yapılan diğer çalışmalarda da kurumların genel olarak program, çalışan, denetim, yönetim, bütçe hizmetleri ve fiziksel koşulların yetersizliği gibi konularda sorunlar yaşadıkları görülmektedir. Yine bu sorunların başında özellikle fiziksel koşulların yetersizliği, yöneticilerin ve öğretmenlerin mesleki yetersizlikleri gelmektedir (Balaban, 2017; Toran, 2019). Bu konular hakkında yapılmış olan yurtdışı çalışmalar da bulunmaktadır (Alvestad ve diğerleri, 2014; Bullough, Hall-Kenyon ve Mackay, 2012; Hui, 2012; Ugaste ve Niikko, 2015).

Bazı araştırmalar genel olarak özetlendiğinde; Yılmaz ve Altınkurt (2011), dershane öğretmenlerinin bu tür kurumlardaki çalışma koşullarını ortaya çıkarmak için yaptıkları çalışmada öğretmenlerin haftada ortalama olarak 50-60 saat çalıştıklarını tespit etmişlerdir. Ancak bu çalışma 
saatleri karşısında hak ettikleri ücreti alamadıkları, sözleşmeli ve ücretli çalışan öğretmenlere göre iş güvenceleri ile sosyal hakları bakımından daha olumsuz koşullarda çalıştıkları görülmüştür. Özpolat (2002) tarafından yapılmış olan araştırma sonucunda öğretmenlerin büyük kısmının maddi bakımdan sıkıntı yaşadıkları ve ek iş yapmak zorunda kaldıkları tespit edilmiştir. Fidan (2008), tarafından yapılan araştırmada da özel okullarda görev yapan öğretmenlerin ders araç-gereçleri ile ilgili bir sıkıntı ve yetersizlik yaşamadıkları, fakat devlet okullarında görev yapan öğretmenlerin ders araç ve gereçlerinin yetersiz olması sebebiyle sorun yaşadıkları sonucuna ulaşılmıştır. Alvestad ve diğerleri (2014) okul öncesi dönemdeki çocukların katılım, oyun ve öğrenme fırsatlarının çoğunlukla sınıf mevcudunun büyüklüğüne ve sınıfın nasıl düzenlendiğine bağlı olduğunu göstermişlerdir. Ugaste ve Niikko (2015) tarafından yapılan çalışmada öğretmenlerin aileler ve eğitim personeli arasındaki yetersiz işbirliği konusunda endişeli olduklarını dile getirmişler, ayrıca çalışan ebeveynlerle istikrarlı iletişimler kurmada güçlükler yaşadıklarını ve meslektaşlarıyla eşit şekilde işbirliği yapamadıklarını belirtmişlerdir.

Bu kapsamda okul öncesi eğitim kurumlarında görev alan öğretmenlerin mesleki sorunları hakkında yapılan çalışmaların yetersiz kaldığı, bu nedenle gerekli çözümlerin ortaya konamadığı görülmektedir. Bu boşluğun giderilebilmesi için devlet ve özel kurumlarda görev yapan öğretmenlerin sorun tanımlarının belirlenmesi ve bu bağlamda çözüm önerileri sunulması gerekmektedir. Ayrıca literatür araştırmalarında okul öncesi öğretmenlerin sorunlarına yönelik karma yöntemin kullanıldığı çalışmaların da çok sınırlı olduğu görülmüştür. Konuya ilişkin nitel araştırmaların örneklem büyüklüklerinin de yetersiz kaldığı söylenebilir. Mevcut çalışma hem öğretmenlerin sorunlarının belirlenmesi hem de sorunların çözümüne yönelik yapılabilecek çalışmalara kaynak oluşturması bakımından önem taşımaktadır.

\section{Yöntem}

\section{Araştırma Deseni}

$\mathrm{Bu}$ çalışmada karma araştırma yöntem ve teknikleri kullanılmıştır. Karma çalışma içerisinde araştırmacı, araştırmanın sorunlarını anlayabilmek için hem nicel (kapalı uçlu) hem de nitel (açık uçlu) verileri toplayarak bu iki veri setini birbiriyle bütünleştirerek, bu bütünleşmenin avantajları doğrultusunda sonuçlara ulaştığı sağlık, sosyal ve davranış bilimleri alanında kullanılan bir araştırma yaklaşımı olarak tanımlanmaktadır (Creswell, 2017). Bu çalışmada özel ve devlet okullarında okul öncesi öğretmenlerinin mesleki sorunlarını derinlemesine incelemek amacıyla nitel yaklaşım kullanılırken, bu yaklaşımları istatistiksel olarak destekleyerek araştırma bulgularının genellenebilirliğini arttırmak için nicel araştırma yönteminden de yararlanılmıştır.

$\mathrm{Bu}$ kapsamda okul öncesi öğretmenlerinin sorun tanımlarının incelenmesini amaçlayan bu çalışmada en uygun yöntem olarak karma araştırma yönteminin kullanılmasına karar verilmiştir. Nicel veriler Kişisel Bilgi Formu, nitel veriler ise Öğretmen Görüşme Formu ile toplanmıştır.

\section{Çalışma Grubu}

İstanbul ili Anadolu Yakası'nda devlet okullarında ve özel okul öncesi eğitim kurumlarında görev yapmakta olan okul öncesi öğretmenleri çalışma grubunu oluşturmaktadır. 2017-2018 eğitim-öğretim yılında İstanbul ili Anadolu Yakası'nda devlet okullarında ve özel okul öncesi eğitim kurumlarında görev yapmakta olan, kartopu örnekleme yoluyla seçilmiş 118 okul öncesi öğretmeni araştırmanın katılımcılarını oluşturmuştur. Kartopu örnekleme yöntemi içerisinde öncelikle evrene ait birimlerden birisi ile temas kurulur. Bu birimin yardımı ile ikinci birime, ikinci birimin yardımıyla üçüncü birime gidilir. Bu şekilde, bir kartopunun büyümesi şeklinde örneklemin alanı genişler (Yazıcıoğlu ve Erdoğan, 2004). Bu çalışmada veri toplama süreciyle birlikte nitel verilerin işlenmesi eş zamanlı olarak gerçekleştirilmiştir. Yeni temaların oluşmadığı görülünce çalışma grubunun yeterli doygunluğa eriştiği düşünülmüş, bu nedenle 118 katılımcıdan sonra tekrar veri toplanmamıştır.

Çalışma grubuna ait bilgiler incelendiğinde; devlet okullarında çalışan öğretmenlerin 17'si (\%30,4) 
Öğretmenlerin Mesleki Sorun Tanımları: ...

18-25, 17'si (\%30,4) 26-30, 15'i (\%26,8) 31-35, 3’ü (\%5,4) 36-40 yaş aralığında, 4'ü $(\% 7,1)$ ise 40 ve üzeri yaştadır. Özel okullarda çalışan öğretmenlerin ise 18'i (\%29,0) 18-25, 27'si (\%43,5) 26-30, 10'u (\%16,1) 31-35, 3'ü $(\% 4,8)$ 36-40 yaş aralığında, 4'ü $(\% 6,5)$ ise 40 ve üzeri yaştadır. Medeni durum bakımından devlet okullarında çalışan öğretmenlerin 30'u $(\% 53,6)$ evli, $26^{\prime}$ sı $(46,4)$ bekâr; özel okullarda çalışan öğretmenlerin 31'i (\%50,0) evli, 31'i (\%50,0) bekârdır. Çocuğa sahip olma durumu bakımından devlet okullarında çalışan öğretmenlerin 24'ünün $(\% 42,9)$ çocuğu varken, 32'sinin $(\% 57,1)$ çocuğu bulunmamakta, özel okullarda çalışan öğretmenlerin 20'sinin (\%32,3) çocuğu varken, 42' sinin $(\% 67,7)$ çocuğu bulunmamaktadır. Öğrenim durumu bakımından devlet okullarında çalışan öğretmenlerin $18^{\prime} \mathrm{i}$ $(\% 32,1)$ ön lisans, 38'i $(\% 67,9)$ lisans mezunu; özel okullarda çalışan öğretmenleri ise 6'sı $(\% 9,7)$ lise, 30'u $(\% 48,4)$ ön lisans, 25'i $(\% 40,3)$ lisans, 1'i $(\% 1,6)$ lisansüstü mezunudur. Katılımcıların çalışma yılı incelendiğinde; devlet okullarında çalışan öğretmenlerin 5'i (\%8,9) 0-1 yıl, 20'si (\%35,7) 1-5 yıl, 20'si (\%35,7) 6-10 yıl, 5'i (\%8,9) 11-15 yıl, 4'ü (\%7,1) 16-20 yıl, 1'i (\%1,8) 21 yıl ve üzeri süre ile çalışmaktayken; özel okullarda çalışan öğretmenlerin 7'si (\%11,3) 0-1 yıl, 24'ü (\%38,7) 1-5 yıl, 21'i (\%33,9) 6-10 yıl, 4'ü (\%6,5) 11-15 yıl, 3'ü (\%4,8) 16-20 yıl, 3’ü (\%4,8) 21 yıl ve üzeri süreyle çalışmaktadır.

\section{Veri Toplama Araçları}

Kişisel Bilgi Formu. Araştırmacı tarafından hazırlanmış olan Kişisel Bilgi Formunda, katılımcıların cinsiyet, yaş, medeni durum, öğrenim durumu, gelir durumu, mesleki çalışma yılı ve günlük çalışma saati gibi katılımcının sosyo-demografik özelliklerini belirlemeye yönelik sorular bulunmaktadır. Araştırmacının hazırlamış olduğu "Kişisel Bilgi Formu" çalışma grubuna uygulanmadan önce 2 uzmana gösterilmiş, uzman görüşü alınmış ve gerekli düzenlemeler yapılarak formun son hali oluşturulmuştur. Kişisel Bilgi Formunda yer alan soruların geçerliliği, okul öncesi eğitimi alanında doktora eğitimini tamamlamış 2 uzmanın fikir birliği ile sağlanmıştır.

Öğretmen Görüşme Formu. Öğretmen Görüşme Formunda okul öncesi öğretmenlerinin sorun tanımlarının belirlenmesine yönelik olarak 1 açık uçlu soru "Okul öncesi öğretmeni olarak yaşadığınız sorunlar nelerdir?" şeklinde yöneltilmiştir. Bu soru genel olarak öğretmenlerin anaokullarındaki sorun tanımlarından oluşmaktadır. Araştırmacı tarafından hazırlanan "Öğretmen Görüşme Formu" çalışma grubuna uygulanmadan önce 2 uzmana gösterilmiş, uzman görüşü alınmış ve gerekli düzenlemeler yapılarak formun son hali oluşturulmuştur. Araştırma soruları, konuya ilişkin önceki literatür çalışmalarında kullanılan görüşme formları ve anketler dikkate alınarak hazırlanmıştır. Hazırlanan bu soruların geçerliliği, Kişisel Bilgi formunda olduğu gibi görüşme formunun hazırlanması ardından okul öncesi eğitimi alanında doktora eğitimini tamamlamış 2 uzmanın fikir birliği ile sağlanmıştır.

\section{Veri Toplama Süreci ve Etik ilkeler}

Veri toplama sürecinde araştırmacı tarafından geliştirilen formlar uzman görüşü alınarak İstanbul Okan Üniversitesi Etik Kurul onayına sunulmuştur. Araştırmanın 11.12.2017 tarihli 89 toplantı sayısı etik kurul kararı ile onayı alınmıştır. Araştırmada gönüllülük esas alınmıştır. Araştırmaya katılan öğretmenlere Öğretmen Gönüllü Katılım Formu gerekli bilgilendirme yapılarak doldurtulmuştur. Katılımcılara ulaşmada kartopu yöntemi kullanılmıştır. Araştırmacı, okul öncesi öğretmenleri ile önceden randevu alarak bireysel olarak görüşme sağlamış ve öğretmenlerden görüşme formlarını doldurmaları istenmiştir. Veri toplama sürecinde araştırmacı tarafından geliştirilen formlar, katılımcılara yüz yüze dağıtılarak öğretmenlerden düşüncelerini özgürce ifade etmeleri istenmiştir. Öğretmenlerin özgürce cevap verebilmeleri ve herhangi bir kısıtlanma hissetmemeleri adına açık uçlu genel bir soru tercih edilmiştir. Görüşme formu aracilığıyla toplanan veriler değerlendirilerek yorumlanmıştır. Veri toplama süreci Ocak 2018-Mart 2018 ayları arasında gerçekleşmiştir.

\section{Verilerin Analizi}

Bu çalışmada nitel verilerin analizinde içerik analizi kullanılmıştır. İçerik analizi, elde edilen verileri açıklayacak kavramlara ve ilişkilere ulaşmayı amaçlamaktadır. İçerik analizinde yapılan temel işlem, birbirine benzeyen verileri belirli kavramlar ve temalar çerçevesinde bir araya getirmek ve bunları okuyucunun anlayabileceği bir biçimde organize ederek yorumlamaktır (Yıldırım ve Şimşek, 2006). 
Veri analizi sürecinde öncelikle katılımcıların sorulara verdikleri yanıtlara ilişkin benzerlikler bir araya getirilerek temalar oluşturulmuştur. Bu temalar "Çalışma Saatleri", "Değersizlik", "Maaş", "Okul Şartları", "Sınıf Düzeni", "Veliler" ve "Sınıf Materyalleri" olarak sıralanmıştır. Daha sonra bu temaları oluşturan farklı alt boyutlar kategorize edilmiştir. Temalar ve alt boyutlarının belirlenmesi ardından devlet okullarında ve özel okullarda görev yapan öğretmenlerin verdikleri yanıtların alt boyutlar açısından karşılaştırılmasına olanak sağlanmıştır. Öğretmenlerin verdikleri yanıtlar Microsoft Excel programı kullanılarak dijital ortama aktarılmış ve elde edilen benzer yanıtlar sayısallaştırılmıştır. Nitel verilerin çözümlenmesi yaklaşık 1 ay sürmüştür. Okul öncesi öğretmenler ise çalıştıkları kuruma göre ÖK (Özel Kurum) ve DK (Devlet Kurumu) şeklinde kodlanmıştır.

Nicel verilerin analizinde ise, tanımlayıcı istatistiklerden yüzde ve frekans analizi kullanılmıştır. İki grup arasında betimleyici istatistik ile frekans dağılımları bulunarak gruplar arası farklılaşma düzeylerini analiz etmek amacı ile çapraz tablo (crosstab) ve ki kare analizleri kullanılmıştır. Çalışma kapsamında yüzde değerler hesaplanırken sorun belirten öğretmen sayısı göz önünde bulundurulmuştur. Bir öğretmen birden fazla sorun belirtebildiği için frekans değerleri örneklem sayısı ile uyumlu olmayabilir.

\section{Bulgular}

\section{Araştırmanın Nicel Bulguları}

Araştırmanın nicel bulguları kapsamında öncelikle “Okul öncesi öğretmenlerin maaş, çalışma saati, yaz tatili süresi, sömestr tatili süresi ve çocuklardan ayrı mola süreleri çalışılan kurum tipine göre farklılaşmakta mıdır?" sorusuna yanıt aranmıştır. Öğretmenlerin maaş, çalışma saati, yaz tatili süresi, sömestr tatili süresi ve çocuklardan ayrı mola sürelerine ilişkin tanımlayıcı istatistikler Tablo 1'de gösterilmiştir.

\section{Tablo I}

Öğretmenlerin, Maaş, Çalışma Saati, Yaz Tatili Süresi, Sömestr Tatili Süresi ve Çocuklardan Ayrı Mola Değişkenlerine İlişkin Tanımlayıcı Istatistikler

\begin{tabular}{|c|c|c|c|c|c|c|c|c|c|}
\hline & & \multicolumn{2}{|c|}{ Devlet } & \multicolumn{2}{|c|}{ Özel } & \multicolumn{2}{|c|}{ Toplam } & \multirow[b]{2}{*}{$\bar{x}$} & \multirow[b]{2}{*}{$\mathrm{p}$} \\
\hline & & $\mathrm{N}$ & $\%$ & $\mathrm{~N}$ & $\%$ & $\mathrm{~N}$ & $\%$ & & \\
\hline \multirow{5}{*}{ Maaş } & Asgari ücret altı & 0 & 0,0 & 8 & 12,9 & 8 & 6,8 & \multirow{5}{*}{22,753} & \multirow{5}{*}{, $000^{*}$} \\
\hline & Asgari ücret & 5 & 8,9 & 14 & 22,6 & 19 & 16,1 & & \\
\hline & $1.401-2000$ & 19 & 33,9 & 8 & 12,9 & 27 & 22,9 & & \\
\hline & $2001-3000$ & 12 & 21,4 & 32 & 51,6 & 44 & 33,9 & & \\
\hline & $3001-4000$ & 20 & 35,7 & 0 & 0 & 20 & 16,9 & & \\
\hline \multirow{4}{*}{ Çalışma Saati } & 3-4 saat & 1 & 1,8 & 1 & 1,6 & 2 & 1,7 & \multirow{4}{*}{87,795} & \multirow{4}{*}{, $000^{*}$} \\
\hline & 5-6 saat & 49 & 87,5 & 2 & 3,2 & 51 & 43,2 & & \\
\hline & $7-8$ saat & 5 & 8,9 & 24 & 38,7 & 29 & 24,6 & & \\
\hline & 9-10 saat & 1 & 1,8 & 35 & 56,5 & 36 & 30,5 & & \\
\hline \multirow{4}{*}{ Yaz Tatili Süresi } & 1-2 hafta & 7 & 12,5 & 16 & 25,8 & 23 & 19,5 & \multirow{4}{*}{43,083} & \multirow{4}{*}{, $000^{*}$} \\
\hline & 3-4 hafta & 9 & 16,1 & 3 & 4,8 & 12 & 10,2 & & \\
\hline & 5-6 hafta & 2 & 3,6 & 30 & 48,4 & 32 & 27,1 & & \\
\hline & $7-8$ hafta & 38 & 67,9 & 13 & 21,0 & 51 & 43,2 & & \\
\hline \multirow{3}{*}{ Sömestr Tatil Süresi } & 0 & 1 & 1,8 & 6 & 9,7 & 7 & 5,9 & \multirow{3}{*}{55,744} & \multirow{3}{*}{, $000^{*}$} \\
\hline & 1 hafta & 0 & 0,0 & 36 & 58,1 & 36 & 30,5 & & \\
\hline & 2 hafta & 55 & 98,2 & 20 & 32,3 & 75 & 63,6 & & \\
\hline \multirow{3}{*}{$\begin{array}{c}\text { Çocuklardan Ayrı } \\
\text { Mola }\end{array}$} & Var & 8 & 14,3 & 45 & 72,6 & 53 & 44,9 & \multirow{2}{*}{40,414} & \multirow{2}{*}{, $000^{*}$} \\
\hline & Yok & 48 & 85,7 & 17 & 27,4 & 65 & 55,1 & & \\
\hline & Toplam & 56 & 100,0 & 62 & 100,0 & 118 & 100,0 & & \\
\hline
\end{tabular}

${ }^{*} \mathrm{p}<.05$

Tablo 1 incelendiğinde devlet ve özel okullarda görev yapan okul öncesi öğretmenlerinin maaşlarının anlamlı düzeyde farklılaştığı görülmektedir $(\bar{x}=22,753 ; p<0,05)$. Yapılan çapraz tablo analizine göre, özel okulda görev yapan öğretmenlerin asgari ücret ve asgari ücret altında maaş alma oranlarının devlet okulunda görev yapan öğretmenlere göre daha yüksek olduğu sonucuna ulaşılmıştır. Ayrıca, devlet okulu öğretmenlerinin asgari ücret altında maaş almadığı tespit edilmiştir. 
Öğretmenlerin Mesleki Sorun Tanımları: ...

Devlet ve özel okullarda görev yapan okul öncesi öğretmenlerinin çalışma süreleri incelendiğinde anlamlı düzeyde farklılaşma olduğu görülmektedir $(\bar{x}=87,795 ; \mathrm{p}<0,05)$. Devlet okulunda görev yapan öğretmenlerin çalışma saatleri çoğunlukla 5-6 saat arası iken, özel okullarda görev yapan öğretmenlerin çalışma saatlerinin çoğunlukla 9-10 saat aralığında olduğu tespit edilmiştir.

Devlet ve özel okullarda görev yapan okul öncesi öğretmenlerinin yaz tatili sürelerinin anlamlı düzeyde farklılaştığ tespit edilmiştir $(\bar{x}=43,083 ; p<0,05)$. Devlet okullarında görev yapan öğretmenlerin yaz tatili süreleri çoğunlukla 7-8 hafta olduğu görülürken özel okullarda görev yapan öğretmenlerin yaz tatili sürelerinin 5-6 hafta arasında olduğu görülmektedir.

Devlet ve özel okullarda görev yapan okul öncesi öğretmenlerinin sömestr tatili süreleri anlamlı düzeyde farklılaşmaktadır $(\bar{x}=55,744 ; p<0,05)$. Özel okullarda görev yapan öğretmenlerin sömestr süreleri çoğunlukla 1 hafta iken devlet okullarında görev yapan öğretmenlerin neredeyse tamamının sömestr sürelerinin 2 hafta olduğu tespit edilmiştir.

Devlet ve özel okullarda görev yapan okul öncesi öğretmenlerinin çocuklardan ayrı mola kullanma durumun anlamlı düzeyde farklılaştığı görülmektedir $(\bar{x}=40,414 ; \mathrm{p}<0,05)$. Devlet okullarında görev yapan öğretmenlerin genellikle çocuklardan ayrı mola kullanma durumları yokken özel okullarda görev yapan öğretmenlerin çoğunlukla çocuklardan ayrı mola yapabildikleri sonucuna ulaşılmıştır.

Araştırmada ikinci olarak "Sınıftaki öğretmen sayısı, sınıfta yardımcı personel, çalışılan yaş grubu, sınıftaki öğrenci sayısı ve kurumdaki hizmet yılı çalışılan kurum tipine göre farklılaşmakta mıdır?" sorusuna yanit aranmıştır.

\section{Tablo II}

Öğretmenlerin Sınıftaki Öğretmen Sayısı, Sınıfta Yardımoı Personel, Çalışılan Yaş Grubu, Sinıftaki Öğrenci Sayısı ve Kurumda Hizmet Yılı Değişkenlerine İlişkin Tanımlayıcı İstatistikler

\begin{tabular}{|c|c|c|c|c|c|c|c|c|c|}
\hline & & \multicolumn{2}{|c|}{ Devlet } & \multicolumn{2}{|c|}{ Özel } & \multicolumn{2}{|c|}{ Toplam } & \multirow[b]{2}{*}{$\bar{x}$} & \multirow[b]{2}{*}{$\mathrm{p}$} \\
\hline & & $\mathrm{N}$ & $\%$ & $\mathrm{~N}$ & $\%$ & $\mathrm{~N}$ & $\%$ & & \\
\hline \multirow{5}{*}{$\begin{array}{c}\text { Sinıftaki } \\
\text { Öğretmen Sayısı }\end{array}$} & 1 & 52 & 92,9 & 18 & 29,0 & 70 & 59,3 & \multirow{5}{*}{53,129} & \multirow{5}{*}{, $000^{*}$} \\
\hline & 2 & 3 & 5,4 & 43 & 69,4 & 46 & 39,0 & & \\
\hline & 3 & 0 & 0,0 & 1 & 1,6 & 1 & 0,8 & & \\
\hline & 4 & 1 & 1,8 & 0 & 0,0 & 1 & 0,8 & & \\
\hline & Toplam & 56 & 100,0 & 62 & 100,0 & 118 & 100,0 & & \\
\hline \multirow{2}{*}{$\begin{array}{c}\text { Sinifta Yardımcı } \\
\text { Personel }\end{array}$} & Var & 31 & 55,4 & 27 & 43,5 & 58 & 49,2 & \multirow{2}{*}{1,642} & \multirow{2}{*}{ 136 } \\
\hline & Yok & 25 & 44,6 & 35 & 56,5 & 60 & 50,8 & & \\
\hline \multirow{3}{*}{$\begin{array}{c}\text { Çalışılan Yaş } \\
\text { Grubu }\end{array}$} & $36-48$ ay & 5 & 8,9 & 17 & 27,4 & 22 & 18,6 & \multirow{3}{*}{14,764} & \multirow{3}{*}{, $001^{*}$} \\
\hline & $49-60$ ay & 42 & 75,0 & 25 & 40,3 & 67 & 56,8 & & \\
\hline & $61-72$ ay & 9 & 16,1 & 20 & 32,3 & 29 & 24,6 & & \\
\hline \multirow{5}{*}{$\begin{array}{c}\text { Sınıftaki Öğrenci } \\
\text { Sayısı }\end{array}$} & 9 ve alt1 & 0 & 0 & 7 & 11,3 & 7 & 5,9 & \multirow{5}{*}{57,142} & \multirow{5}{*}{, $000^{*}$} \\
\hline & $10-15$ & 5 & 8,9 & 27 & 43,5 & 32 & 27,1 & & \\
\hline & $16-20$ & 18 & 32,1 & 28 & 45,2 & 46 & 39,0 & & \\
\hline & 21-25 & 15 & 26,8 & 0 & 0 & 15 & 12,7 & & \\
\hline & 26 ve üzeri & 18 & 32,1 & 0 & 0 & 18 & 15,3 & & \\
\hline \multirow{7}{*}{$\begin{array}{l}\text { Kurumda } \\
\text { Hizmet Yllı }\end{array}$} & $0-1$ y1l & 17 & 30,4 & 20 & 32,3 & 37 & 31,4 & \multirow{6}{*}{8,767} & \multirow{6}{*}{ 119 } \\
\hline & $2-5$ yil & 32 & 57,1 & 23 & 37,1 & 55 & 46,6 & & \\
\hline & $6-10$ y1l & 7 & 12,5 & 14 & 22,6 & 21 & 17,8 & & \\
\hline & $11-15$ y1l & 0 & 0 & 3 & 4,8 & 3 & 2,5 & & \\
\hline & $16-20$ y1l & 0 & 0 & 1 & 1,6 & 1 & 0,8 & & \\
\hline & 21 yıl ve üzeri & 0 & 0 & 1 & 1,6 & 1 & 0,8 & & \\
\hline & Toplam & 56 & 100,0 & 62 & 100,0 & 118 & 100,0 & & \\
\hline
\end{tabular}

* $\mathrm{p}<.05$

Tablo 2 incelendiğinde özel ve devlet okulunda görev yapan okul öncesi öğretmenlerinin sınıftaki öğretmen sayısı dağılımlarının anlamlı düzeyde farklılaştığı görülmektedir $(\bar{x}=53,129 ; p<0,05)$. Devlet okullarında genellikle sınıfta 1 öğretmen olduğu, özel okullarda ise genellikle 2 öğretmen olduğu tespit edilmiştir.

Devlet ve özel okullarda çalışılan yaş grupları incelendiğinde gruplar arasındaki frekans 
dağılımlarının anlamlı düzeyde farklı olduğu görülmektedir $(\bar{x}=14,764 ; p<0,05)$. Devlet okulunda görev yapan okul öncesi öğretmenlerinin çalıştıkları yaş grubunun yüzdesel olarak 49-60 ay kategorisinde olduğu, özel okulların ise her yaş grubunda dağılım gösterdiği sonucuna ulaşılmıştır.

Devlet ve özel okullarda, sınıftaki öğrenci sayısı bakımından gruplar arasındaki frekans

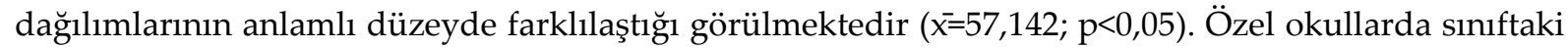
öğrenci sayısı 20'yi geçmezken devlet okullarında sınıftaki öğrenci sayısının 21 ve üzerinde olduğu tespit edilmiştir. Araştırmaya katılan öğretmenlerin \%16,9'unun sınıf mevcutlarının fazla olmasını sorun olarak belirttiği tespit edilmiştir. Bu sorun tanımını özel okul öğretmenlerinin \%12,9'u devlet okulu öğretmenlerinin ise \% 21,4'ü belirtmiştir. Sorun tanımı ile ilgili sonuçlar incelendiğinde devlet okullarındaki öğretmenlerin sınıf mevcudu ile ilgili daha fazla sorun belirttiği görülmektedir. Bu sorun tanımı özel okul öğretmenlerinden ÖK41 tarafından "kalabalık gruplarla yaş grubunda hareket dinamiğinden dolayı çalışmanın ve yapılacak etkinliklere yetişebilmekte zorlanma" şeklinde açıklanırken devlet okullarındaki öğretmenlerden DK38 tarafından ise "sınıfların kalabalık olması, özel gereksinimli öğrencilerin sayısının birden fazla olması ve tam gün eğitime zorlaması" şeklinde ifade edilmiştir.

Devlet ve özel okullarda görev yapan okul öncesi öğretmenlerin sınıflarında yardımcı personel olup olmama durumları ve kurumdaki hizmet yılları arasında anlamlı düzeyde farklılaşma olmadığı tespit edilmiştir $(\mathrm{p}>0,05)$.

Araştırmada üçüncü olarak "Sınıfın fiziksel imkanları, sınıfta materyal yeterliliği, okul yönetimi ile problem ve diğer öğretmenlerle problemler çalışılan kuruma tipine göre farklılaşmakta mıdır?" sorusuna yanıt aranmıştır.

\section{Tablo III}

Öğretmenlerin Sinıfların Fiziksel İmkanları, Sinıfta Materyal Eksikliği, Okul Yönetimi İle Problem ve Diğgr Öğretmenlerle Problem Değişkenlerine İlişkin Tanımlayıcı İstatistikler

\begin{tabular}{|c|c|c|c|c|c|c|c|c|c|}
\hline & & \multicolumn{2}{|c|}{ Devlet } & \multicolumn{2}{|c|}{ Özel } & \multicolumn{2}{|c|}{ Toplam } & \multirow[b]{2}{*}{$\bar{x}$} & \multirow[b]{2}{*}{$\mathrm{p}$} \\
\hline & & $\mathrm{N}$ & $\%$ & $\mathrm{~N}$ & $\%$ & $\mathrm{~N}$ & $\%$ & & \\
\hline \multirow{3}{*}{$\begin{array}{l}\text { Sınıfin Fiziksel } \\
\text { İmkânları }\end{array}$} & İyi & 19 & 33,9 & 31 & 50,0 & 50 & 42,4 & \multirow{3}{*}{3,136} & \multirow{3}{*}{ 208 } \\
\hline & Orta & 33 & 58,9 & 28 & 45,2 & 61 & 51,7 & & \\
\hline & Kötü & 4 & 7,1 & 3 & 4,8 & 7 & 5,9 & & \\
\hline \multirow{3}{*}{$\begin{array}{c}\text { Sinıfta Materyal } \\
\text { Yeterliliği }\end{array}$} & İyi & 14 & 25,0 & 28 & 45,2 & 42 & 35,6 & \multirow{3}{*}{5,777} & \multirow{3}{*}{,056 } \\
\hline & Orta & 33 & 58,9 & 29 & 46,8 & 62 & 52,5 & & \\
\hline & Kötü & 9 & 16,1 & 5 & 8,1 & 14 & 11,9 & & \\
\hline \multirow{2}{*}{$\begin{array}{c}\text { Okul } \\
\text { Yönetimi ile Problem }\end{array}$} & Var & 6 & 10,7 & 13 & 21,0 & 19 & 16,1 & \multirow{2}{*}{2,290} & \multirow{2}{*}{ 103 } \\
\hline & Yok & 50 & 89,3 & 49 & 79,0 & 99 & 83,9 & & \\
\hline \multirow{3}{*}{$\begin{array}{c}\text { Diğer Öğretmenlerle } \\
\text { Problem } \\
\end{array}$} & Var & 7 & 12,5 & 2 & 3,2 & 9 & 7,6 & \multirow{2}{*}{3,592} & \multirow{2}{*}{,060 } \\
\hline & Yok & 49 & 87,5 & 60 & 96,8 & 109 & 92,4 & & \\
\hline & Toplam & 56 & 100,0 & 62 & 100,0 & 118 & 100,0 & & \\
\hline
\end{tabular}

Tablo 3 incelendiğinde devlet ve özel okullarda görev yapan okul öncesi öğretmenlerinin sınıfın fiziksel imkânları, materyal yeterliliği, okul yönetimi ve diğer öğretmenler ile ilgili problem olupolmama durumlarının anlamlı düzeyde farklılaşmadığı görülmektedir ( $p>0,05)$.

\section{Araştırmanın Nitel Bulguları}

Bu çalışma için, özel ve devlette çalışan öğretmenlerin bildirdikleri sorunlar doğrultusunda oluşturulan temalar ve alt boyutları Şekil 1'de yer almaktadır. 
Öğretmenlerin Mesleki Sorun Tanımları: ...

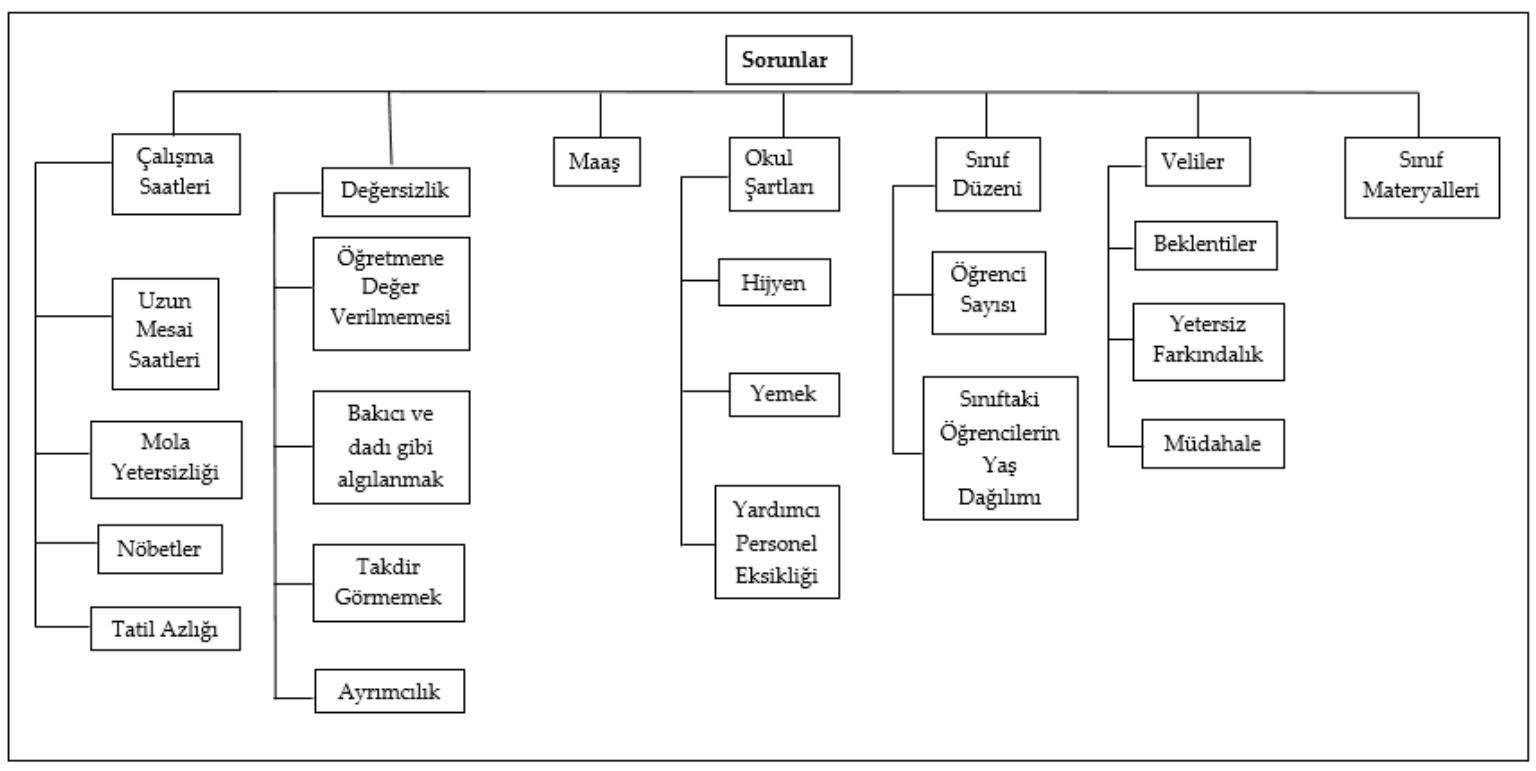

Şekil 1. Öğretmenlerin bildirdikleri temalar ve alt boyutları

Şekil 1'e göre öğretmenlerin bildirdikleri sorunlar Çalışma Saatleri, Değersizlik, Maaş, Okul Şartları, Sınıf Düzeni, Veliler ve Sınıf Materyalleri olmak üzere 7 temadan oluşmaktadır. Çalışma Saatleri teması kapsamında uzun mesai saatleri, mola yetersizliği, nöbetler ve tatil azlığı; Değersizlik teması kapsamında öğretmene değer verilmemesi, bakıcı ve dadı gibi algılanmak, takdir görmemek ve ayrımcılık; Okul Şartları teması kapsamında hijyen, yemek ve yardımcı personel eksikliği; Sını Düzeni teması kapsamında öğrenci sayısı ve sınıftaki öğrencilerin yaş dağılımı; Veliler teması kapsamında beklentiler, yetersiz farkındalık ve müdahale alt boyutlarından meydana gelmiştir.

Araştırmada dördüncü olarak "Mola yetersizliği, okul şartları, sınıf mevcudu, malzeme eksikliği, çalışma saatleri, değersizlik, veliler ve maaş çalışılan kurum tipine göre farklılaşmakta mıdır?" sorusuna yanıt aranmıştır.

Tablo IV

Özel ve Devlet Okullarında Çalışan Öğretmenlerin Sorun Temalarına Yönelik Verdikleri Yanıtların Frekans Dağılımı

\begin{tabular}{|c|c|c|c|c|c|c|c|c|c|}
\hline \multirow[t]{2}{*}{ Temalar } & \multicolumn{3}{|c|}{ Devlet $(\mathrm{N}=56)$} & \multicolumn{3}{|c|}{ Özel (N=62) } & \multicolumn{2}{|c|}{ Toplam(N=118) } & \multirow[t]{2}{*}{$\mathrm{p}$} \\
\hline & $\mathrm{N}$ & Genel \% & $\%$ & $\mathrm{~N}$ & Genel \% & $\%$ & $\mathrm{~N}$ & Genel \% & \\
\hline Mola Yetersizliği & 23 & 62.2 & 41.0 & 14 & 37.8 & 22.5 & 37 & 31.3 & ,031* \\
\hline Okul şartları & 20 & 76.9 & 35.7 & 6 & 23.1 & 9.6 & 26 & 22.0 &, $001^{*}$ \\
\hline Sinif Mevcudu & 12 & 60.0 & 21.4 & 8 & 40.0 & 12.9 & 20 & 16.9 & 232 \\
\hline Malzeme Eksikliği & 12 & 70.6 & 21.4 & 5 & 29.4 & 8.0 & 17 & 14.4 & ,039* \\
\hline Çalışma Saatleri & 1 & 3.8 & 1.7 & 25 & 96.2 & 40.3 & 26 & 22.0 &, $000^{*}$ \\
\hline Değersizlik & 8 & 29.6 & 14.2 & 19 & 70.4 & 30.6 & 27 & 22.8 &, $035^{*}$ \\
\hline Veliler & 8 & 53.3 & 14.2 & 7 & 46.7 & 11.2 & 15 & 12.7 & ,783 \\
\hline Maaş & 0 & 0.0 & 0.0 & 11 & 100.0 & 17.7 & 11 & 9.3 &, $001^{*}$ \\
\hline
\end{tabular}

Tablo 4 incelendiğinde, devlet ve özel okullarda görev yapan öğretmenlerin sorunlara ilişkin vermiş oldukları yanıtlar doğrultusunda oluşturulan temalar ve bu temalara ilişkin frekans dağılımları görülmektedir.

Mola yetersizliği temasına ilişkin sonuçlar incelendiğinde devlet okulunda görev yapan öğretmenler özel okullarda görev yapan öğretmenlere göre bu sorun tanımında daha fazla bildirimde bulundukları görülmektedir. 
"Değersizlik" temasına ilişkin sonuçlar incelendiğinde, devlet okullarında ve özel okullarda çalışan öğretmenlerin sorun belirtme oranlarının anlamlı düzeyde farklılaşttğı görülmektedir ( $p=, 035 ; p<0,05)$. Özel okullarda çalışan öğretmenlerin değersizlik temasına ilişkin sorun bildirme oranının devlet okulundakilere göre daha yüksek olduğu tespit edilmiştir. Araştırmaya katılan öğretmenlerden \% 22,8'i kendilerini mesleki anlamda değersiz hissettiklerini belirtmişlerdir. Özel okullarda görev yapan öğretmenlerin \% 30,6'sı, devlet okulunda görev yapan öğretmenlerin ise \% 14,2'si değersizlik hissi yaşan öğretmenleri oluşturmaktadır. Bu durumda özel okullarda öğretmenlik yapan kişilerin mesleki anlamda daha fazla değersizlik hissi yaşadığı görülmüştür. Özel okul öğretmenlerinden ÖK28 bu konuyu "öğretmene ve mesleğe sayg1 azlığ1, öğretmenlerin vermiş olduğu bilgi-eğitimin karşılığını alamaması" şeklinde açıklamışlardır.

“Çalışma Saatleri" temasına ilişkin sonuçlar incelendiğinde devlet ve özel okullarda çalışan okul öncesi öğretmenlerde anlamlı düzeyde farklılaşma olduğu görülmektedir $(p=, 000 ; p<0,05)$. Özel okulda çalışan öğretmenlerin çalışma saatleri temasına ilişkin sorun bildirme oranının devlet okulundakilere göre daha yüksek olduğu tespit edilmiştir. Öğretmenlerin \%22'si çalışma saatlerini bir sorun olarak görmektedir. Özel okul öğretmenlerinin \%40,3'ü, devlet okulu öğretmenlerinin ise \% 1,7'si çalışma saatleri ile ilgili tatil azlığı, nöbetler ve uzun mesai saatlerini karşılaşılan sorunlar olarak bildirilmiştir. Devlet okulu öğretmenlerinin sorun tanımını sınıftan çıkıp rahatlayabilmek adına mola-dinlenme zamanlarının olmadığı şeklinde ifade ettikleri görülürken, özel okullarda görev yapan öğretmenlerin ise uzun çalışma saatlerini ve tatil azlığını sorun olarak ifade ettikleri görülmektedir. Özel okul öğretmenlerinden ÖK27 bu sorun tanımını “Okul aç1ış ve kapanış saatlerinin uzunluğu, yarıyıl tatilinin olmaması ve yaz tatili sürelerinin azlı̆̆ı" şeklinde ifade ederken, devlet okullarında ise DK8, DK18 ve DK19 "Okul öncesinde hiç teneffüs olmaması en büyük sıkıntılardan biri, ilkokul gibi teneffüs olması gerektiğini düşünüyorum." şeklinde ifade etmiştir. Araştırmaya katılmış olan bir özel okul öğretmeni tarafından bu durum ÖK41 tarafından "Özel sektörde çalışıyor olmak sebebiyle çalışma saatlerinin uzunluğu ve bu saatler aralığında enerjileri yoğun bir grupla çalışıldığı için dinlenme sürelerinin yetersiz gelmesi" şeklinde belirtilmiştir. Devlet okulundan DK43 ise bu durumu "Molamız olmadığı için tuvalet gibi temel ihtiyaçlarımızı karşılarken bile çocukların yalnız kalacağı endişesiyle hareket etmek zorundayız." şeklinde belirtmiştir.

"Okul şartları" temasına ilişkin sonuçlar incelendiğinde devlet ve özel okullarda çalışan öğretmenlerde anlamlı düzeyde farklılaşma olduğu görülmektedir $(p=, 001 ; p<0,05)$. Devlet okulunda çalışan öğretmenlerin özel okulda çalışan öğretmenlere göre ilgili temada daha fazla sorun bildirdiği tespit edilmiştir. Öğretmenlerin, okulun hijyen, yemek, servis imkânları ve personel eksikliği ile ilgili sorun bildirdiği tespit edilmiştir. Okul şartlarından şikâyet eden öğretmenlerin oranı toplamda \%22'dir. Özel okullardaki öğretmenlerin \%9,6'sı bu durumu sorun olarak görürken devlet okullarındaki öğretmenlerin \% 35,7'si okul şartlarının sorun teşkil ettiğini belirtmişlerdir. Bu durumda devlet okullarında görev yapan öğretmenlerin okul şartlarını ile ilgili daha fazla sorun yaşadıkları görülmüştür. Özel okul öğretmenlerinden ÖK25 bu konu hakkında "Yeterince hijyen olmadığı için sorun oluyor." şeklinde açıklama yaparken devlet okulunda görev yapan öğretmenlerden DK48 "Yardımcı personelin olmaması ve yeterli düzeyde temizlik olmaması" şeklinde fikir belirtmiştir.

"Malzeme Eksikliği" temasına ilişkin sonuçlar incelendiğinde devlet ve özel okullarda çalışan öğretmenlerde anlamlı düzeyde farklılaşma olduğu görülmektedir $(p=, 039 ; p<0,05)$. Malzeme eksikliği temasında devlet okulunda çalışan öğretmenlerin özel okulda çalışan öğretmenlere göre daha fazla sorun bildirdiği tespit edilmiştir. Öğretmenlerin \%14,4'ünün malzeme eksikliği konusunda sıkıntı yaşadığı bu öğretmenlerden\% 8'i özel okullarda, \% 21,4'ünün ise devlet okullarında görev yaptığı belirlenmiştir. Sorun tanımını devlet okulu öğretmenlerinden DK39 ve DK12 “Oyuncaklarımızın tam olmasını isterdim." ve özel okul öğretmenlerinden ÖK12 ise "Sınıfta materyallerin, eğitici oyuncakların eksikliği" şeklinde ifade etmişlerdir.

"Veliler" temasına ilişkin sonuçlar incelendiğinde, velilerin beklentileri, farkındalık ve bilinçlilik düzeylerinin yetersiz oluşu ve programa müdahale etmelerine ilişkin sorunlar yer almaktadır. Öğretmenlerin toplamda \% 12,7'si bu konuda sorun yaşadıklarını belirtmiştir. Özel okullarda görev yapan öğretmenlerin $\% 11,2$ 'si devlet okullarındaki öğretmenlerin ise \%14,2'si bu görüşü paylaşmıştır. Özel okul öğretmenlerinden 
ÖK46 bu konudaki fikirlerini "Okul-veli arası iletişimi dengede tutmak öğretmeni yormakta. Beklentilerin farklılaşması öğretmenlerin motivasyonunu düşürmekte" şeklinde belirtirken devlet okulu öğretmenlerinden DK38 ise "Velilerin öğretmenlere karşı olumsuz tutum ve davranışlara sık yönelmesi" şeklinde belirtmiştir.

"Maaş" temasına ilişkin sonuçlar incelendiğinde devlet ve özel okullarda çalışan öğretmenlerde anlamlı düzeyde farklılaşma olduğu görülmektedir $(p=, 001 ; p<0,05)$. Maaş temasında özel okulda çalışan öğretmenlerin devlet okulunda çalışan öğretmenlere göre daha fazla sorun bildirdiği tespit edilmiştir. Araştırmaya katılan öğretmenlerin \%9,3'ü maaş ile ilgili sorun yaşadıklarını tespit edilmiştir. Maaş ile ilgili sorun bildiren okul öncesi öğretmenlerinin tamamının özel kurumlarda görev yaptıkları görülmektedir. Özel okul öğretmenlerinin 17,7'sinin bu sorun tanımını bildirdiği tespit edilmiştir. Sorun tanımını özel okul öğretmenlerinden ÖK31“Maaşların az olması ve sigortaların eksik yatırılması", ÖK12 "Kurumun maaş beklentisini gerekli şekilde gerçekleştirememesi", ÖK25 “Bir öğretmen olarak (yardımcı öğretmen dahi olsa) maaşların asgari ücretin altında olması sorun oluyor" şeklinde ifade etmiştir.

\section{Sonuç ve Tartışma}

Devlet ve özel okul öncesi eğitim kurumlarında görev yapan öğretmenlerin sorunlarına ilişkin yapılan araştırma sonucunda devlet okullarındaki öğretmenlerin, özel okullardaki öğretmenlerden daha fazla molaya ihtiyacı olduğu görülmektedir. Ağgül-Yalçın ve Yalçın (2018), öğretmenlerin okul öncesi etkinliklerin kesintisiz devam ettirilmesini dezavantaj olarak gördüklerini, ara vermeden yapılan çalışmalarda çocukların konudan sıkılarak dikkatlerinin dağıldığını belirtmişlerdir. Aynı zamanda öğretmenlerin dinlenemediklerini, kendilerine vakit ayıramadıklarını ve gün sonunda yorgun düştüklerini ortaya koymuşlardır. Etkinliklerin kesintisiz devam etmesinin çocukların diğer çocuklarla iletişim kuramamasına, oyun oynayıp sosyalleşememelerine sebep olduğu, bunun yanı sıra öğretmenlerin mola yapamamalarının ve ihtiyaçlarını gidermek için zaman ayıramamalarının iş verimlerinin düşmesine neden olduğu sonucuna ulaşılmıştır (Ağgül-Yalçın ve Yalçın, 2018). Araştırmada mola ilgili çıkan sonuçlar değerlendirildiğinde, çalışma saatlerinin devlet okullarında özel okullara oranla daha az olduğu görülürken, mola ihtiyacı hissetme oranının devlet okullarında özel okullara oranla daha fazla olduğu tespit edilmiştir. Bunun nedeni olarak, iki temel faktör düşünülebilir. Birincisi, araştırma bulgularımızda yer alan özel kurumlarda sınıfta iki öğretmen bulunması yaygın iken, devlet kurumlarında bu durumun daha az olduğu görülmektedir. Sınıfta iki öğretmenin bulunmasının aralıklı çalışmayı mümkün kılabileceği düşünülmektedir. Bu bağlamda, devlet kurumlarında sınıfta genelde tek öğretmen bulunmasının mola konusunda daha yüksek düzeyde yetersizlik oluşturabileceği düşünülebilir. İkincisi ise, sınıf mevcutlarının 20 kişinin üzerinde olması da yine öğretmenin iş yükünü artıran, farklı sorunlarla karşı karşıya kalmasına neden olabilecek bir durum olarak düşünülebilir. Dolayısıyla öğretmenlerin iş yükünün artmasına paralel olarak mola ihtiyaçlarının da arttığı ortaya çıkmaktadır. Gün içerisinde verilen molaların, öğretmenlerin ruh halini ve enerjilerini yenileme imkânı sağladığı belirtilmiştir (Kinnunen, de Bloom ve Virtanen, 2019). Ayrıca gün içinde verilen molaların daha sık aralıklarla yapılması ile yorgunluğun azaldığı ve rahatlamanın sağlandığı ilave edilmiştir (Bennett, Bakker ve Field, 2018).

Değersizlik sorununa ilişkin olarak okul öncesi öğretmenlerin görüşleri doğrultusunda, öğretmenin yaptığı işin değersizleştirilmesi, çocuklarla çalışıyor olmaktan dolayı bakıcı veya dadı gibi algılanmaları ve okul yönetimi tarafından takdir göremiyor olmaya ilişkin sorunların bildirildiği görülmektedir. Ocak, Gündüz, Özdemir ve Kaya (2005), toplumun sadece \%11'lik bir kısmının öğretmenliği saygın bir meslek olarak gördüğü, öğretmen adaylarının ise öğretmenlik mesleğini topluma oranla daha fazla saygın gördüğü sonucuna ulaşmıştır. Sucuoğlu ve Kuloğlu (1996), öğretmenlik mesleğinin hak ettiği saygıyı görmediğini, maaşların düşük olduğunu ve bu sorunların tükenmişlik duygusuna sebep olabileceğini belirtmişlerdir. Ağgül-Yalçın ve Yalçın (2018) tarafından yapılan araştırmanın sonuçları da mevcut çalışma sonuçları ile benzerlik göstermektedir. Sonuçlar değerlendirildiğinde özel okul öncesi eğitim kurumlarındaki çalışma saatlerinin daha fazla olması, gelir düzeyinin düşük olması ve mesleki güvencenin daha az olması değersizlik ile ilişkilendirilebilir. Marlow, Inman ve Betancourt-Smith (1996), yaptıkları araştırmaya katılan öğretmenlerin hemen hemen yarısının bazı zamanlarda öğretmenliği bırakmayı düşündüklerini ortaya koymuştur. Bunun 
sebebi olarak öğrencilerden, velilerden, yöneticilerden ve toplumdan bekledikleri saygıyı göremedikleri, zor şartlarda çalıştıkları ve maaşlarının az olması gösterilmektedir. Değersizlik teması ile ilgili sonuçlar incelendiğinde devlet ve özel okullar noktasında anlamlı bir farklılaşma olduğu görülmektedir. Bu farklılaşmanın sebebi olarak devlet kurumlarında görev yapan öğretmenlerin iş güvencelerinin olması, çalışma saatlerinin özel okullara göre daha kısa olması, tatillerinin daha fazla olması, ayrıca aldıkları ücretlerin özel sektöre göre daha iyi düzeyde olması, devlet okulu öğretmenlerinin iş doyumu düzeyini arttırıp motivasyonlarını yükseltiyor olabilir. Bu sebep ile çok fazla sorun belirtmedikleri düşünülebilir. Nitekim özel okullarda görev yapan öğretmenlerin değersizlik teması ile ilgili devlet okulu öğretmenlerine göre daha fazla sorun belirtmelerine sebep olarak, çalışma saatlerinin uzun olması, uzun çalışma saatlerinin ardından nöbet tutmak zorunda kalmaları, ayrıca tatillerinin az olması nedeniyle özel okul öğretmenlerinin çok fazla dinlenme imkanı bulamadıkları düşünülebilir. Tüm bunlara karşın özel okul öğretmenlerinin iş güvencelerinin olmaması, verilen emeğin karşılığında alınan ücretlerin tatmin edici olmaması öğretmenlerinin iş doyumu ve motivasyon düzeylerini düşürebilir. Ayrıca, özel okulların ekonomik kaygısının olması, bu sebeple de veliye daha fazla tolerans gösterilebildiği bilinen bir gerçektir. Bu bağlamda yanlış beklenti ve tutumlar öğretmenlerin kendilerini değersiz hissetmelerine neden olarak düşünülmektedir.

Öğretmenlerin sorun temaları arasında yer alan bir diğer madde çalışma saatleridir. Çalışma saatleri ile ilgili sonuçlar değerlendirildiğinde özel okul öğretmenlerinin büyük çoğunluğunun sorun belirttiği tespit edilmiştir. Bu konuda yapılan çalışmalar arasında Akman, Taşkın, Özden ve Çörtü (2010), okul öncesi öğretmenlerinin yasal olarak dinlenme haklarının olmadığını aralıksız görev yaptıklarını ve bu durumun tükenmişlik düzeylerini etkileyeceğini belirtmiştir. Bauer ve diğerleri (2007), tam zamanlı görev yapan öğretmenlerin haftada 51 saatten fazla mesai yaptıklarını ortaya çıkarmışlardır. Özel kurumlardaki öğretmenlerin iş kaygıları ve işlerini kaybetmek istememeleri sebebiyle fazla mesai ve çalışma saatlerine uydukları düşünülebilir. Uzun mesai saatleri ile çalışanların hem fiziksel hem de psikolojik olarak iş verimi ve iş doyumunu olumsuz etkileyebileceği düşünülmektedir. Çalışmaya katılan öğretmenlerinin çalıştıkları yaş grubunun küçük olması ve uzun mesai saatlerinin daha yıpratıcı olacağı düşünülmektedir. Öğretmenlerin asıl sorunlarından birisi olan nöbet tutmanın da dersten sonra öğretmenlere dinlenme imkânı vermediği sorun tanımı haline geldiği düşünülebilir. Ayrıca, katılımcıların çalışma saatleri teması ile ilgili vermiş oldukları cevaplar incelendiğinde sorun tanımını belirtme şekilleri arasında da bir farklılaşma olduğu görülmektedir.

Diğer bir sorun tanımı ise sınıf düzeni teması içerisindeki sınıf mevcutlarının yoğun olmasıdır. Sınıf mevcutlarının yanında öğrencilerin yaş dağılımı ve kaynaştırma öğrencileri de öğretmenlerin bildirdiği sorunlar olarak belirlenmiştir. Sirkeci (2010), özel ve devlet okullarında görev alan öğretmenlerin sınıf mevcudu düşük olan sınıflarda daha az sorun yaşadıklarını tespit etmiştir. Sınıf mevcudunun artması öğretmenlere sınıf düzenini ve disiplini sağlamada zorluk çıkardığı sonucuna ulaşılmıştır. Şahin ve Dursun (2009), okul öncesi dönemde öğretmen-çocuk iletişiminin çocuk üzerinde etkisi olduğunu ve öğretmenin iş doyumunun önemli olduğunu belirtmişlerdir. Demato ve Curcio (2004) ise gelecek nesilleri yetiştiren öğretmenlerin iş doyumlarının belirlenmesinin önemli olduğunu belirtmişlerdir. Çetin (2002) ve Çınar (2004) tarafından yapılan çalışmalar sonucunda sınıf mevcutlarının sınıf büyüklüklerine göre fazla olmasının öğrencilerin eğitimlerini verimli şekilde sürdürememelerine sebep olduğu tespit edilmiştir. Aynı zamanda Ural ve Ramazan (2007) ve Kök ve diğerleri (2007) de yaptıkları çalışmalarda benzer sonuçlara ulaşmışlardır. Smith ve Glass (1979), sınıf mevcudunun az olmasının daha kaliteli sınıf ortamları, daha iyi öğrenci tutumları ve daha fazla öğretmen memnuniyeti ile ilişkili olduğunu tespit etmişlerdir.

Öğretmen sorunlarından en önemlilerinden birisinin “öğrenci sayısının fazlalığı ve fiziki olanaklara dayanan zorluklar" ile "devlet tarafından temin edilmesi gereken sosyal olanakların yetersizliği" ile ilgili olduğu görülmektedir. Ağgül-Yalçın ve Yalçın (2018) tarafından yapılan araştırma sonucunda öğretmenlerin sınıf koşullarının öğrenci sayısına uygun olmadığını, böylece oyun ve drama gibi faaliyetlerin olumsuz etkilendiğini, öğretmenlerin çocuklarla iletişime geçmede ve ilgilenmede sorun yaşadıkları tespit edilmiştir. Yaman (2010), sınıf mevcudunun fazla olduğu durumlarda araç ve gereklerin yetersiz kaldığını, öğrencilerin derse ilgisiz kaldığını ve öğretmenlerin disiplin kurmada sorun yaşadığı sonucuna ulaşmıştır. Smilansky (1984), öğretmenlerin stres nedenlerinin idari değil, çoğunlukla sınıfla ilişkili olduğunu ortaya koymuştur. 
Pan ve Qin (2007), okul şartları ve öğretmenlerin iş tatmin seviyeleri arasında anlamlı bir ilişki olduğunu belirlemiştir. Jenkinson ve Chapman (1990), fiziksel olarak rahatsız edici ve tehlikeli olmayan yerlerin öğretmenlerin iş doyumunu etkilediğini belirtmiştir. Okul öncesi eğitim dönemindeki öğrencilerin fizyolojik, bilişsel ve psikolojik gelişim sürecinde olması ile fiziksel koşullardan olumsuz derecede etkilenmeleri sonucunda birçok problem ile karşılaşacakları düşünülmektedir. Çocukların bu eğitim sürecinde yaşlarına uygun materyaller ve koşul yetersizlikleri ile karşılaşmalarının öğretmenlerin işlerini de daha fazla zorlaştıracağı düşünülebilir. Bunun yanı sıra okullarda çocuk güvenliğinin sağlanabilmesi için fiziki şartların iyileştirilmesi gerektiği düşünülmektedir. Çalışkan-Maya (2006) maaşların ile çalışma saatleri, sınıf mevcudu ve eğitim kadrosunun öğrenci sayısına oranı yönünden de $A B$ ülkeleri ile Türkiye arasında önemli farklılıklar olduğunu belirtmiştir. Sınıfların kalabalık olmasının araç-gereç yetersizliğine, öğrencinin derse ilgisine ve öğretmenlerin disiplini sağlamada zorlanmasına sebep olduğu düşünülebilir. Öğrenci dağılımlarının homojen yapılmaması farklı gelişim özelliğine sahip öğrencilerin birlikte eğitim görmesini zorunlu hale getirmesi, öğrencilerin farklı ihtiyaçlarının olması ile öğretmenlerin bu farklı ihtiyaçlara aynı anda cevap vermesi gerektirdiğini düşündürebilir. Kaynaştırma öğrencilerinin gelişim özelliklerinin farklı olması, bu durumda eğitimlerinin de özel olarak planlanması gerektiği için öğretmenlerin sorun yaşamalarına neden olduğu düşünülmektedir.

Okul öncesi öğretmenlerinin önemli problemlerinden bir diğeri de veliler ile yaşanan iletişim sorunlarıdır. Sadık (2006), yaptığı çalışmada velilerin sorunlu davranışları dışsal etkenlere bağladığını ve başkalarını suçlama eğilimde olduklarını belirtmiştir. Sirkeci (2010), velilerin istenmeyen bir durumda öğretmenlerin çocuğa kızmalarını ve dayak atmasını beklediğini, öğretmenlerin ise velilerden çocuklarına dayak atmamalarını, sevgi ve ilgi gösterilmelerini beklediği sonucuna ulaşılmıştır. Öğretmenlerin ve velilerin beklentilerinin eğitim süreci, okul öncesi eğitim, okul ve öğretmen ile sağladıkları işbirliği, velilerin tutum ve davranışları ile ilgili problemlerin öğretmen sorunları arasında önemli bir yeri olduğu düşünülmektedir. Öğretmen ve öğrenci ile velilerin davranış ve tutumlarının eğitimde önemli etkileri olduğu düşünülmektedir. Öğrencilerin okul öncesi öğretimde adaptasyon sürecini rahat bir şekilde atlatabilmesi sürecinde veli farkındalığı olmamasının öğretmenlerin karşılaştığı problemleri arttırabileceği düşünülmektedir. Bu durumda velilerin rollerini etkin bir şekilde üstlenememeleri, iş birliğinde bulunmamalarının sebebinin eğitim süreci ve öğretmenle ilgili yanlış beklentiler içinde olmalarıyla ilişkilendirilebilir. Okul öncesi dönem hakkında farkındalık sürecinin gelişmemiş olmasının sorun düzeyini yükselttiği düşünülmektedir.

Öğretmenlerin sorun temaları içinde yer alan diğer sorunlardan birisi de sınıf materyallerinin yetersizliğidir. Fidan (2008), tarafından yapılan araştırma sonucunda özel okul öğretmenlerinin değil devlet okulundaki öğretmenlerin araç-gereçler ile ilgili eksiklikten dolayı sıkıntı yaşadıklarını sonucuna ulaşılmıştır. Genel olarak bakıldığında özel okulların devlet okullarından daha iyi fiziki şartlara sahip olduğu ve materyal eksikliği yaşamadıkları görülmektedir. Özel okulların velilerden ücret alması ve okulların rekabet içerisinde olması sonucunda okulun fiziki şartlarını ve materyallerini önemsedikleri düşünülebilir.

Maaş ile ilgili sorunlar öğretmenlerin sorun temalarından biri olarak belirlenmiştir. Sağlam ve ÇiçekSağlam (2005), öğretmelerin yaşadıkları sorunlardan en büyügünün düşük gelir olduğunu belirtmişlerdir. Yılmaz ve Altınkurt (2011), özel dershane öğretmenlerinin aldıkları ücretin çalışma saatlerini karşılamadığını, kadrolu, sözleşmeli ve ücretli öğretmenlere göre iş güvencesi ve sosyal haklar bakımından daha olumsuz şartlar altında çalıştıkları tespit edilmiştir. Erdem (2008), öğretmenlerin aldıkları ücretin akademik yayınları takip etmeye yetmediğini ve yaptıkları işin karşılığını alamadıklarını düşündüklerini belirtmiştir. Özdemir (1986) ve Özdayı (1990) da çalışmalarında benzer sonuçlara ulaşmışlardır. Özpolat (2002), öğretmenlerin çoğunun geçim sıkıntısı yaşadığını ve ek iş yapmak zorunda kaldıklarını ortaya koymuştur. Türkan (1999), öğretmenlerin maaş yetersizlikleri yüzünden saygı görmedikleri düşüncesinde olduklarını belirtmiştir. Uğraş (2009), özel dershane öğretmenlerine zamanında ödeme yapılmadığı, sigorta primlerinin eksik yatırıldığı ya da asgari ücret aldıklarını tespit etmiştir. Bu çalışmaların yanı sıra Akiba, Chiu, Shimizu ve Liang (2012), öğretmen maaşları yüksek olan ülkelerin ulusal başarılarının daha fazla olduğunu belirtmişlerdir. Litt ve Turk (1985), az maaş ve düşük statü gibi sorunların iş stresi tatmininde önemli olduğunu tespit etmiştir. Yapılan çalışmaların değerlendirmesi sonucunda tüm toplumlarda önemli bir yeri olan öğretmenlerin yaşam 
standartlarını yükseltecek gelir düzeyinde olmadıkları için bu konu öğretmenlerin en önemli sorularından biri olarak düşünülebilir. Çalışmaya katılan öğretmenlerin elde ettikleri kazancın kendileri için yetersiz olduğunu algılamaları "maaş yetersizliğini" belirgin bir sorun tanımı haline getirmektedir. Ayrıca yasal olarak asgari ücret altında maaşın olamayacağı bilinirken araştırma bulgularımıza göre öğretmenlerin asgari ücret altında maaş aldığı veya fazla maaş alsa dahi sigortaların düşük maaş üzerinde ödendiği tespit edilmiştir.

Çalışmadan elde edilen sonuçlar genel olarak şu şekilde sıralanabilir:

Devlet okullarında görev yapan öğretmenlerin sınıf mevcudu, mola yetersizliği, okul şartları, malzeme eksikliği ve veliler konularında daha fazla sorun yaşadıkları, özel okullarda görev yapan öğretmenlerin ise maaş, değersizlik ve çalışma saatleri konularında daha fazla sorun yaşadıkları tespit edilmiştir.

Özel okullarda görev yapan öğretmenlerin maaşları ve çalışma saatleri devlet okulunda görev yapan öğretmenlere göre daha yüksektir.

Özel okullarda görev yapan öğretmenlerin çalışma saatleri ve sömestr süreleri devlet okulunda görev yapan öğretmenlere göre daha düşüktür.

Devlet okullarında görev yapan öğretmenlerin genellikle çocuklardan ayrı mola kullanma durumları yokken, özel okullarda görev yapan öğretmenlerin çoğunlukla çocuklardan ayrı mola kullanma imkanları vardır.

Devlet okullarındaki sınıflarda genellikle bir öğretmen, özel okullarda genellikle iki öğretmen bulunmaktadır.

Devlet okulunda görev yapan okul öncesi öğretmenlerinin çalıştıkları yaş grubu 49-60 ay kategorisinde iken özel okullarda görev yapan okul öncesi öğretmenler her yaş grubu ile çalışmaktadır.

\section{Öneriler}

Araştırma bulguları sonucunda özel okullarda ve devlet okullarında okul öncesi öğretmenlerin sorunlarına yönelik olarak okul yöneticileri ve akademisyenlere öneriler sunulmuştur. Öncelikle özel ve devlet okullarındaki okul yönetimlerinin, araştırmamızın bulgularından faydalanarak okul öncesi öğretmenlerinin sorunlarının çözümü ya da mevcut sorunların en aza indirilebilmesi adına gerekli planlama yapmaları önerilmektedir.

Yapılan araştırma sonucunda öğretmenlerin mola yetersizliğini sorun olarak belirttiği tespit edilmiştir. Öğretmenlerin zaruri ihtiyaçlarını giderebilmeleri ve ders verimliliğinde devamlılığın sağlanabilmesi adına yasal olarak mola - dinlenme haklarının olması, bu bağlamda gerekli çalışmaların yapılması önerilmektedir.

Mevcut araştırma sonucunda öğretmenlerinin bina ve materyal yetersizliği ile ilgili sorun bildirdikleri tespit edilmiştir. Bu bağlamda altyapı ve bina yetersizliklerinin giderilmesi hususunun, gerekli kurumlarca desteklenmesi önerilebilir. Ayrıca sınıf mevcutlarının yüksek ve okul şartlarının yetersiz olduğu tespit edilmiştir. Okul şartlarının ve sınıf mevcutlarının yönetmeliğe uygun olarak düzenlenmesi gerektiği düşünülmektedir. Gerekli düzenlemelerin yapılıp sonrasında ise, denetlemelerle devamlılığının sağlanması önerilmektedir.

Araştırma sonucunda özel okullarda görev yapan öğretmenlerin büyük çoğunluğunun günde 9-10 saat çalıştığı, ayrıca yasal olarak asgari ücret altında maaş ödemesinin suç olduğu bilindiği halde asgari ücretin altında maaş ile çalıştırılan ya da maaşı yüksek dahi olsa sigorta ödemelerinin asgari ücret üzerinden yapıldığı tespit edilmiştir. Bu sorunların hem 5580 sayılı Özel Okullar Kanununa hem de İş Kanununa aykırı olduğu bilinmektedir. Bu usulsüzlüklerin daha iyi denetlenmesi ve hukuksal yaptırımların daha kuvvetli olması gerektiği düşünülmektedir. Devlet ve özel okullarda görev yapan öğretmen ücretlerinin belirli bir standarda taşınmasıyla hem eğitim sürecinin daha verimli hem de öğretmenlerin memnuniyet düzeylerinin artacağı düşünülmektedir. Bu bağlamda yetkili makamlar tarafından yapılan çalışmaların düzenlenmesi, gerekli denetimlerin yapılması ve gerekli yaptırımların uygulanması önerilmektedir. Genel olarak özel kurumlara da çalışma saatleri, maaş vb. ile ilgili konularda kamu kurumlarındaki gibi bir standart getirilmesi önerilebilir. 
Araştırma sonucunda okul öncesi öğretmenlerinin kendilerini değersiz hissettikleri tespit edilmiştir. Öğretmenlerin kendilerini değersiz hissetmelerine sebep olan velilerin yanlış beklenti ve tutumları eğitim sürecine dair zorluk oluşturabilmektedir. Bu bağlamda velilerin de seminer, konferans gibi çalışmalarla eğitilmesinin okul öncesi eğitim ile ilgili olumlu toplumsal algı gelişmesine katkı sağlayacağı düşünülmektedir. Ayrıca, öğretmenlerin kendilerini değersiz hissetmelerine sebep olan etkenlerin tespit edilmesi ve ortadan kaldırılmasına yönelik çalışmaların yapılması önerilmektedir.

Son olarak özel okullarda yaşanan sorunlarında kendi içlerinde farklılaştığı tespit edilmiş, bu nedenle akademisyenler tarafından yapılabilecek bu türde bir çalışmanın özel okullar kapsamındaki kolejler, butik anaokulları vb. kurumlarda yeni bir çalışma olarak uygulanabileceği önerilmektedir. Bu doğrultuda okul öncesi eğitime gerekli önem verilerek okul öncesi eğitimin amaçlarına yönelik uygulamalar gerçekleştirilmelidir. Ayrıca çalışmanın 128 okul öncesi öğretmen ile sınırlı olması nedeniyle gelecekte yapılacak araştırmalarda daha geniş örneklemler üzerinde anket tekniği kullanılarak öğretmenlerin sorunlarının daha kapsamlı incelenmesi, bunun yanı sıra öğretmenlerin yaşadıkları sorunların akademik başarı, öğretmen performansı ve okul/öğrenme iklimi üzerine etkilerinin araştırılması önerilebilir. Böylece öğretmenlerin yaşadıkları sorunların genel okul başarısı ve eğitim kalitesini arttırmak amacıyla alınması gereken önlemlerin öncelikleri tespit edilebilir.

\section{Yazar(lar)ın Beyanı}

Araştırmacıların katkı oranı beyanı: Araştırmacılardan Cansu Başturan, araştırmanın giriş bölümüne, veri toplama sürecine, verilerin çözümlemesine ve tartışma bölümüne; Ertan Görgü ise araştırmanın giriş bölümüne, verilerin çözümlemesine ve tartışma bölümüne katkı sunmuştur. Araştırmaya birinci yazar \%60, ikinci yazar \%40 oranında katkı sundukların beyan etmektedirler.

Çatışma beyanı: Araştırmada, yazarların kendi içinde ve diğer kişi/kurum/kuruşlarla herhangi bir çıkar çatışması söz konusu değildir.

Destek ve teşekkür: Araştırmanın yürütülmesinde herhangi bir kurumdan destek alınmamıştır.

\section{Kaynaklar}

Ağgül-Yalçın F. ve Yalçın M. (2018). Okul öncesi öğretmenlerin okul öncesi eğitimin sorunlarıyla ilgili görüşleri: Ağrn ili örneği. İlköğretim Online, 17(1), 367-383.

Akiba, M., Chiu, Y-L., Shimizu, K. ve Liang, G. (2012). Tearcher salary and national achievement: A crossnational analysis of 30 countries. International Journal of Educational Research, 53, 171-181.

Akkurt, Z. (2008). Okul öncesi öğretmenlerinin iş doyumu ve tükenmişlik düzeylerinin incelenmesi (İstanbul Pendik örneği) (Yüksek lisans tezi). Selçuk Üniversitesi, Sosyal Bilimler Enstitüsü, Konya.

Akman, B., Taşkın, N., Özden, Z. ve Çörtü, F. (2010). Okul öncesi öğretmenlerinde tükenmişlik üzerine bir çalışma. İlköğretim Online, 9(2), 807-815.

Alabay, E. ve Yağan, A. G. (2015). Hazır planlarda yer alan fen etkinliklerinin okul öncesi eğitim programı temel özellikleri açısından incelenmesi. Uluslararası Eğitim Bilimleri Dergisi, 2(4), 1-21.

Alvestad, T., Bergem, H., Eide, B., Johansson, J. E., Os, E., Palmadottir H., ... Winger, N. (2014). Challenges and dilemmas expressed bu teachers working in toddler groups in the Nordic countries. Early Childhood Development and Care, 184(5), 671-688.

Atay, M. (2005). Çocukluk döneminde gelişim. Ankara: Kök Yayıncılık.

Balaban, E. (2017). Türkiye'de okul öncesi eğitim ve okul öncesi öğretmenlerinin yönetim sürecinde karşılaştıkları sorunlar (Yüksek lisans projesi). Trakya Üniversitesi, Sosyal Bilimler Enstitüsü, Edirne.

Bauer, J., Unterbrink, T., Hack, A., Pfeifer, R., Buhl-Griesshaber, V., Muller, U., ... Wirsching, M. (2007). Working conditions, adverse events and mental health problems in a sample of 949 German teachers. 
International Archives of Occupational and Environmental Health, 80(5), 442-449.

Bennett, A., Bakker, A.B. ve Field, J.G. (2018). Recovery from work-related effort: A meta-analysis. Journal of Organizational Behavior, 39(3), 262-275.

Bullough, R. V., Hall-Kenyon, K. M. ve MacKay, K. L. (2012). Head Start teacher well-being: Implications for policy and practice. Early Childhood Education Journal, 40(6), 323-331.

Burhan, T. (2016). Devlete bağlı anaokulu ile özel anaokulunda çalışan öğretmenlerin öz yeterlik inancı ve iş doyumu düzeylerinin incelenmesi (Yüksek lisans tezi). Beykent Üniversitesi, Sosyal Bilimler Enstitüsü, İstanbul.

Creswell, J.W. (2017). Karma yöntem araştırmalarına giriş (1. bs.). (Çev. Ed. M. Sözbilir). Ankara: Pegem Akademi Yayınları.

Çalışkan-Maya, İ. (2006). AB sürecinde Türkiye ile AB ülkeleri eğitim istatistiklerinin 59. karşılaştırması. Türk Eğitim Bilimleri Dergisi, 4(4), 375-396.

Çetin, Y. (2002). Illköğretim 4. ve 5. sını öğretmenlerinin sınıfta karşılaştıkları disiplin problemleri. (Yüksek lisans tezi). Çukurova Üniversitesi, Sosyal Bilimler Enstitüsü, Adana.

Çetinkaya, B. (2010). Türkiye'de okul öncesi eğitim ve sorunlar (Yüksek lisans tezi). Beykent Üniversitesi, Sosyal Bilimler Enstitüsü, İstanbul.

Çınar, O. (2004). Kalabalık sınıflar. XIII. Ulusal Eğitim Bilimleri Kurultayı. Malatya: İnönü Üniversitesi Ĕ̆itim Fakültesi.

Demato, D. ve Curcio, C. (2004). Job Satisfaction of elemantary school counselors. Professional School Counseling, 7(4), 236-246.

Demir, M. K. ve Arı, E. (2013). Öğretmen sorunları-Çanakkale ili örneği. Ondokuz Mayıs Üniversitesi Eğitim Fakültesi Dergisi, 32(1), 107-126.

Ekici, F. Y. (2013). Okul öncesi eğitim kurumlarındaki aile katılım çalısmalarına katılan ve katılmayan ailelerin çocuklarının sosyal beceri ve problem davranışlar açısından karşılaştırılması (Yüksek lisans tezi). Marmara Üniversitesi, Eğitim Bilimleri Enstitüsü, İstanbul.

Ekinci, A. (2010). İlköğretim okullarında çalışan müdür ve öğretmenlerin mesleki sorunlarına ilişkin görüşleri. Dicle Üniversitesi Ziya Gökalp Eğitim Fakültesi, 9(2), 734-748.

Erdem, M. (2008). Öğretmenlere göre kamu ve özel liselerde iş yaşamı kalitesi ve örgütsel bağhllıkla ilişkisi (Doktora tezi). Ankara Üniversitesi, Eğitim Bilimleri Enstitüsü, Ankara.

Fidan, N. K. (2008). İlköğretimde araç gereç kullanımına ilişkin öğretmen görüşleri. Afyon Kocatepe Üniversitesi Eğitim Fakültesi Kuramsal Ĕ̆itimbilim Dergisi, 1(1), 48-61.

Genç, M. (2006). Özel ve devlet okulu öğretmenlerinin iş doyum düzeylerinin karşılaştırılması (Yüksek lisans tezi). İstanbul Yeditepe Üniversitesi, Sosyal Bilimler Enstitüsü, İstanbul.

Gürkan, T. ve Haktanır, G. (2006). Okul öncesi eğitimi genel müdürlüğü okul öncesi eğitim programı (36-72 aylık çocuklar için). Ankara: MEB Yayınları.

Hui, L. (2012). Chinese kindergarten teachers' salaries: The problems and causes. Early Childhood Education, 36(12), 6-10.

Jenkinson F. R. ve Chapman, D. W. (1990). Job satisfaction of Jamaican elementary school teachers. International Review of Education, 36(3), 299- 313.

Kandemir, Y. (2015). Devlet okulu öğretmenlerinin özel okullara ilişkin tutumlarının incelenmesi (Yüksek lisans tezi). Yeditepe Üniversitesi, Eğitim Bilimleri Enstitüsü, İstanbul.

Kinnunen, U., de Bloom, J. ve Virtanen, A. (2019). Do older teachers benefit more from workday break recovery than younger ones? Scandinavian Journal of Work and Organizational Psychology, 4(1), 1-15. 
Öğretmenlerin Mesleki Sorun Tanımları...

Koşucu, E. (2016). Okul öncesi öğretmenliği programlarındaki "çocukta oyun gelişimi dersinde" yaratıcı drama yönteminin öğrenci başarısına etkisi (Yüksek lisans tezi). Ankara Üniversitesi, Eğitim Bilimleri Enstitüsü, Ankara.

Kök, M., Küçükoğlu, A., Tuğluk, M. N. ve Koçyiğit, S. (2007). Okul öncesi eğitiminin sorunlarına ilişkin öğretmen görüşleri (Erzurum örneği). Atatürk Üniversitesi Kazım Karabekir Eğitim Fakültesi Dergisi, 8(16), $160-171$.

Litt, M. D. ve Turk, D. C. (1985). Sources of stress and dissatisfation in experienced high school teachers. The Journal Of Educational Research, 78(6), 178-185.

Marlow, L., Inman, D. ve Betancourt-Smith, M. (1996). Teacher job satisfaction. Natchitoches, LA: Northwestern State University.

Meydan S. (1984). Türkiye'de okul öncesi eğitime bakış. İstanbul: Ya-Pa Yayınları.

National Centre for Educational Statistics (1996). Digest of education statistics. US: Department of Education Office of Educational Research and Improvement.

Ocak, G., Gündüz, M., Özdemir, M. A. ve Kaya, Ü. (2005). Öğretmenlerde sosyal statü sorunları. S. Sarı, İ. Kara ve Ş. Kapıkıran (Ed.), XIV. Ulusal Eğitim Bilimleri Kongresi, Denizli: Pamukkale Üniversitesi Eğitim Fakültesi.

Oktay, A. (2000). Yaşamın sihirli yilları: okul öncesi dönem. İstanbul: Epsilon Yayıncılık.

Özdayı, N. (1990). Resmi ve özel liselerde çalışan öğretmenlerin iş tatmini ve iş streslerinin karşılaştırmalı analizi (Doktora tezi). İstanbul Üniversitesi, Sosyal Bilimler Enstitüsü, İstanbul.

Özdemir, S. (1986). Kamu ödeme sistemi içinde öğretmen ücretlerinin yeri ve să̆ladığı doyum (Yüksek lisans tezi). Ankara Üniversitesi, Sosyal Bilimler Enstitüsü, Ankara.

Özpolat, A. (2002). Sosyolojik açıdan öğretmenlik mesleği ve öğretmenlerin toplumdaki yeri, öğretmen, öğrenci ve veli algılarına göre: Zonguldak örneği (Doktora tezi). İstanbul Üniversitesi, Sosyal Bilimler Enstitüsü, İstanbul.

Pan, X. ve Qin, Q. (2007). An analysis of the relation between secondary school organizational climate and teacher job satisfaction. Chinese Education \& Society Journal, 40(5), 65-77.

Poyraz, H. (2001). Okul öncesi eğitimin ilke ve yöntemleri. Ankara: Anı Yayınc1lık.

Sadık, F. (2006). Öğrencilerin istenmeyen davranışları ve bu davranışlarla baş edebilme stratejilerini öğretmen öğrenci ve veli görüşlerine göre incelenmesi (Doktora tezi). Çukurova Üniversitesi, Sosyal Bilimleri Enstitüsü, Adana.

Sağlam, M. ve Çiçek-Sağlam, A. (2005). Öğretmenlik mesleğinin maddi yönüne ilişkin genel bir değerlendirme. Türk Ĕ̆itim Bilimleri Dergisi, 3(3), 317-328.

Sirkeci, B. (2010). Özel ve devlet ilköğretim okulları birinci kademesindeki öğretmenlerin, sınıf yönetiminde karşılaştıkları disiplin sorunları ve yaklaşım biçimleri (Yüksek lisans tezi). Fırat Üniversitesi, Sosyal Bilimleri Enstitüsü, Elazı ̆̆.

Smilansky, J. (1984). External and internal correlates of teachers' satisfaction and willingness to report stress. British Journal of Educational Psychology, 54(1), 84-92.

Smith, M. L. ve Glass, G. V. (1979). Relationship of class-size to classroom processes, teacher satisfaction and pupil affect: A meta-analysis. San Francisco: Far West Laboratory of Educational Research and Development.

Sucuoğlu, B. ve Kuloğlu, N. (1996). Özürlü çocuklarla çalışan öğretmenlerde tükenmişliğin değerlendirilmesi, Türk Psikologlar Dergisi, 10(36), 44-60.

Şahin, H. ve Dursun, A. (2009). Okul öncesi öğretmenlerinin iş doyumları: Burdur örneği. Mehmet Akif Ersoy Üniversitesi Ĕ̆itim Fakültesi Dergisi, 9(18), 160-174.

Taner-Derman, M. ve Başal, H. A. (2010). Cumhuriyetin ilanından günümüze Türkiye'de okul öncesi eğitim 
ve ilköğretimde niceliksel ve niteliksel gelişmeler. Uluslararası Sosyal Araştırmalar Dergisi, 3(11), 560-569.

Temel, Z. F., Kandır, A., Erdemir, N. ve Koçer Çiftçibaşı, H. (2005). Okul öncesi eğitimde proje yaklaşımı ve program örnekleri. İstanbul: Morpa Kültür Yayınları.

Toran, M. (2019). Does sense of efficacy predict classroom management skills? An analysis of the pre-school teacher's professional competency. Early Child Development and Care, 189(8), 1271-1283.

Türkan, M. (1999). Ortaöğretim (lise) öğretmenlerinin beklenti ve sorunları (Doktora tezi). Dokuz Eylül Üniversitesi, Eğitim Bilimleri Enstitüsü, İzmir.

Ugaste, A. ve Niikko, A. (2015). Identifying the problems that Finnish and Estonian teachers encounter in preschool. European Early Childhood Education Research Journal, 23(4), 423-433.

Uğraş, K. (2009). Özel dershanelerde çalışan tarih öğretmenlerinin sorunları ve çözüm önerileri (Ankara ili örneği) (Yüksek lisans tezi). Gazi Üniversitesi, Sosyal Bilimler Enstitüsü, Ankara.

Ural, O. ve Ramazan, O. (2007). Türkiye'de okul öncesi eğitimin dünü ve bugünü. S. Özdemir, H. Bacanlı ve M. Sözer (Ed.), Türkiye'de okul öncesi eğitim ve ilköğretim sistemi temel sorunlar ve çözüm önerileri. Ankara: Türk Eğitim Derneği.

Yaman, E. (2010). Kalabalık sınıfların etkileri: Öğrenciler ne düşünüyor? Kastamonu Eğitim Dergisi, 18(2), 403414.

Yaşar, Ş. (2004). Okul öncesi eğitim ilke ve yöntemleri. Eskişehir: Anadolu Üniversitesi Yayınları.

Yazıcıoğlu, Y. ve Erdoğan, S. (2004). SPSS uygulamalı bilimsel araştırma yöntemleri. Ankara: Detay Yayıncılık.

Yıldırım, A. ve Şimşek, H. (2006). Sosyal bilimlerde nitel araştırma yöntemleri (5. bs.). Ankara: Seçkin Yayıncılık.

Yılmaz, K. ve Altınkurt, Y. (2011). Göreve yeni başlayan özel dershane öğretmenlerinin kurumlarındaki çalışma koşullarına ilişkin görüşleri. Dumlupınar Üniversitesi Kuram ve Uygulamada Eğitim Bilimleri Dergisi, $11(2), 635-650$. 
Öğretmenlerin Mesleki Sorun Tanımları...

\section{EXTENDED ABSTRACT}

\section{Introduction}

Even though pre-school education is undeniably significant, certain problems come into play in institutions which offer pre-school education. The Ministry of National Education of Turkey developed certain standards to be followed both by public and private institutions offering pre-school education. However, differences still existing between these institutions pave the way for certain problems herewith. It is asserted that persons who are the most affected by these problems are teachers. It is necessary to identify and solve the problems confronted by teachers so that teachers who are responsible for educating students can deliver highly satisfactory and good quality education (Taner-Derman and Başal, 2010). As per the report submitted by All Teachers' Unification and Solidarity Association of Turkey to the Turkish National Commission for UNESCO, it was found that teachers were in general challenged by issues such as financial difficulties, security, law, teacher distribution, appointments and categorization of teachers (Demir and Ari, 2013).

It is discerned that crucial developments for pre-school education started in Turkey in the 1960s, however, these developments did not satisfy the needs of educational system in terms of quality and quantity (TanerDerman and Başal, 2010). Also through studies, it was ascertained that teacher criteria were important to an effective education and instruction (Ekinci, 2010). In this conjunction, it is emphasized that the identification and solution of problems of teachers employed in pre-school education is essential. In researches performed with the participation of pre-school teachers, it was found that teachers were faced with problems such as the insufficiency of physical resources, shortage of course materials, deficiencies in the program and its content and obstacles created by school administrations (Kök et al., 2007). In another study, it is discerned that educational institutions generally had problems in issues such as the insufficiency of program, employees, control mechanism, administration, budgetary services and physical conditions (Balaban, 2017).

In this context, the identification of occupational problems of teachers employed by institutions for preschool education is important to the creation of necessary solutions. It is thought that this study will both help to identify problems and make contributions to the literature.

\section{Method}

In the study, mixed research methods and techniques were utilized. The study group of the research was comprised of a total of 118 pre-school teachers employed by public and private institutions of pre-school education which were located in Anatolian side of Istanbul province of Turkey. In order to collect personal information of participants, a personal information form was used. Qualitative data of the research were obtained through interviews with teachers. The content analysis was applied to the qualitative data obtained through research.

\section{Results and Conclusion}

Problems reported by teachers are categorized under seven themes, that is, 'Work Hours', 'Feeling Valueless', 'Wage', 'School Conditions', 'Order of the Classroom', 'Students' Legal Guardians' and 'Course Materials'.

The theme of 'Work Hours' is composed of sub-dimensions of 'long working hours', 'lack of breaks', 'guard duty' and 'insufficiency of vacations. The theme of 'Feeling Valueless' is composed of sub-dimensions of 'not valuing the teacher', 'being perceived as care-taker and nanny', 'not being appreciated' and 'discrimination'. The theme of 'School Conditions' is composed of sub-dimensions of 'hygiene', 'food' and 'lack of support staff'. The theme of 'Order of the Classroom' is composed of sub-dimensions of 'number of students' and 'age distribution of students in the classroom'. The theme of 'Students' Legal Guardians' is composed of sub-dimensions of 'expectations', 'insufficient level of awareness' and 'intervention'.

Upon the review of qualitative data of the research in terms of frequencies, it was found that there was a statistically significant difference between teachers of public and private pre-schools, and in this sense, 
teachers employed by public pre-schools complained about the lack of breaks, problems associated with school conditions, highly populated classrooms and shortage of course materials more than teachers of private pre-schools did whereas teachers of private pre-schools complained about long work hours, feeling valueless and wage problems more than teachers of public pre-schools did. Nevertheless, it was ascertained that, in terms of 'Students' Legal Guardians' theme, there was no statistically significant difference between teachers of public and private pre-schools.

Upon the review of quantitative data of the research, it was discerned that there was again a statistically significant difference between teachers of public and private pre-schools, and in this regard, teachers of public pre-schools had higher wages, worked for shorter periods of time, had longer summer holidays and had longer semester vacations than teachers of private pre-schools whereas classrooms of private pre-schools were less populous, there were more teachers per student at private pre-schools and teachers of private pre-schools had breaks for longer periods.

At the end of the research, it was recommended that, at public pre-schools, the problem associated with the insufficiency of break time for teachers should be overcome, the number of teachers should be increased, the number of students should be lowered in populous classrooms and physical resources \& materials should be provided at satisfactory levels. In a similar vein, it was recommended that work hours of teachers of private pre-schools should be reduced, more equitable wages should be offered to teachers of private pre-schools and, to this end, controls should be performed in accordance with rules and, so that semester and summer holidays would be long enough for teachers of private pre-schools, their duration should be extended. 